\title{
LEAD US NOT INTO (UNWARRANTED) TEMPTATION: A PROPOSAL TO REPLACE THE ENTRAPMENT DEFENSE WITH A REASONABLE-SUSPICION REQUIREMENT
}

\author{
MAURA F. J. Whelan ${ }^{\dagger}$
}

The use of stings and scams to root out vice and corruption has received renewed interest in the last five years with the revelations of Abscam in $1980^{1}$ and, more recently, the acquittal of bankrupt auto magnate John Z. DeLorean in his celebrated cocaine trial. ${ }^{2}$ DeLorean and some of the Abscam defendants claimed entrapment, a doctrine under which the defendant, although in fact guilty of the crime for which an indictment has been secured, nevertheless seeks acquittal on the theory that the police have induced the commission of a crime that would not have been committed otherwise. ${ }^{3}$ DeLorean prevailed on the entrapment defense, ${ }^{4}$ but all of the Abscam defendants were convicted. ${ }^{5}$

† B.A. 1980, Swarthmore College; J.D. Candidate, 1986, University of Pennsylvania. The author wrote this Comment while a student at the University of Pennsylvania.

1 See Maitland, High Officials Are Termed Subjects of a Bribery Investigation by F.B.I., N.Y. Times, Feb. 3, 1980, $\S 1$, at 1, col. 1 .

2 See Lindsey, Jurors Cite Entrapment and Failure to Prove Case, N.Y. Times, Aug. 17, 1984, at A1, col. 3. (1972).

3 See W. LaFave \& A. Scott, Handbook on Criminal Law $\S 48$, at 369

- See infra text accompanying notes 36-37.

- See United States v. Jenrette, 744 F.2d 817 (D.G. Cir. 1984) (affirming conviction); United States v. Silvestri, 719 F.2d 577 (2d Cir. 1983) (affirming conviction); United States v. Weisz, 718 F.2d 413 (D.C. Cir. 1983) (affirming convictions of Weisz and Ciuzio), cert. denied, 104 S. Ct. 1285, 1305 (1984); United States v. Thompson, 710 F.2d 915 (2d Cir. 1983) (denying motion for retrial), cert. denied, 104 S. Ct. 702 (1984); United States v. Kelly, 707 F.2d 1460 (D.G. Cir.) (reversing district court's dismissal and reinstating jury conviction), cert. denied, 104 S. Ct. 264 (1983); United States v. Williams, 705 F.2d 603 (2d Gir.) (affirming conviction), cert. denied, 104 S. Ct. 524 (1983); United States v. Myers, 692 F.2d 823 (2d Cir. 1982) (Myers II) (affirming conviction), cert. denied, 461 U.S. 961 (1983); United States v. Carpentier, 689 F.2d 21 (2d Cir. 1982) (affirming conviction), cert. denied, 459 U.S. 1108 (1983); United States v. Alexandro, 675 F.2d 34 (2d Gir.) (affirming conviction), cert. denied, 459 U.S. 835 (1982); United States v. Jannotti, 673 F.2d 578 (3d Cir.) (en banc) (reversing district court's judgment of acquittal and reinstating jury conviction), cert. denied, 457 U.S. 1106 (1982); United States v. Myers, 635 F.2d 932 (2d Cir.) (Myers I) (denying dismissal of indictment), cert. denied, 449 U.S. 956 (1980).

In addition, several of the Abscam defendants unsuccessfully asserted the so-called "due process" defense, arguing that the defendants, predisposition notwithstanding, should be acquitted because of the government's overinvolvement in the commission of the crimes. See, e.g., Williams, 705 F.2d at 619-22 (asserting due process defense as well as entrapment); Myers $I I, 692$ F.2d at 835-36 (six of seven defendants relying on due process and other defenses); Jannotti, 673 F.2d at 606-10 (asserting due process 
Although the last decade has seen an unprecedented use of undercover operations by the Federal Bureau of Investigation (FBI) and other federal law enforcement agencies, ${ }^{6}$ the Supreme Court has not reevaluated the entrapment doctrine in almost ten years. ${ }^{7}$ Recent events suggest that it is high time the defense was seriously reconsidered. Reform is unlikely to come from the judicial branch, as the Supreme Court has expressed its unwillingness to alter current doctrine. However, the Court has invited legislative action in the entrapment area. ${ }^{8}$ In the wake of Abscam, committees in both houses of Congress turned their attention to entrapment and other problems raised by certain undercover operations. ${ }^{\circ}$ Although legislation was introduced during the ninety-eighth Congress, ${ }^{10}$ no action was taken on it before the end of

and entrapment defenses).

${ }^{6} \mathrm{~J}$. Edgar Hoover was a staunch opponent of undercover activities on the part of the FBI. After his death in 1972, the Bureau gradually increased its use of undercover tactics. It was not until after 1975 that these operations took on real significance; between 1977 and 1981, the number of undercover operations per year increased rapidly, from 53 in 1977 to 463 in 1981. Select Comm. To StUdy UnDERCover Activities of Components of the Department of Justice, Final Report to the U.S. Senate, S. ReP. No. 682, 97th Cong., 2d Sess. 34-42 (1982) [hereinafter cited as Select Commitree RePorT]. Total appropriations to the Department of Justice for undercover activities increased from \$1 million in 1977 to over \$12 million in 1984. Subcomm. ON Civil and ConstrTutional Rights of THE House CoMm. ON THE Judiciary Together with Dissenting Views, FBI Undercover Operations, H.R. Doc. No. 267, 98th Cong., 2d Sess. 12-13 (1984) [hereinafter cited as EDWARDS COMMITTEE REPORT].

7 The last entrapment case decided by the Supreme Court was Hampton v. United States, 425 U.S. 484 (1976). Prior to that, its most recent consideration had been in United States v. Russell, 411 U.S. 423 (1973). Strictly speaking, Hampton is not an entrapment case. It deals instead with the due process defense, see infra note 202, which was also asserted together with the entrapment defense in Russell. The entrapment defense was successfully asserted for the first time in the federal courts seventy years ago, see Woo Wai v. United States, 223 F. 412 (9th Cir. 1915), and received the Supreme Court's imprimatur seventeen years later, see Sorrells v. United States, 287 U.S. 435 (1932).

${ }^{8}$ See United States v. Russell, 411 U.S. 423, 433 (1973).

- In response to the resignation of Senator Harrison A. Williams, Jr., the United States Senate created the Select Committee to Study Law Enforcement Undercover Activities of Components of the Department of Justice [hereinafter referred to as the Select Committee]. See S. Res. 350, 97th Cong., 2d Sess., 128 Cong. Rec. S2800-03 (daily ed. Mar. 24, 1982). The Select Committee held 14 days of hearings. See Law Enforcement Undercover Activities: Hearings Before the Select Comm. to Study Law Enforcement Undercover Activities of Components of the Department of Justice, 97th Cong., 2d Sess. (1982) [hereinafter cited as Hearings]. At the close of the 97th Congress, the Select Committee published its findings. See Select CommitTeE RePORT, supra note 6. In reaction to Abscam, Congressman Don Edwards, former FBI agent and chairman of the House Subcommittee on Civil and Constitutional Rights, held 21 days of hearings over a period of four years to investigate the propriety of federal undercover operations. See EDWARDS COMMITTEE REPORT, supra note 6, at 1-2.

${ }^{10}$ Early in the 98th Congress, Senator Charles McC. Mathias, Jr., chairman of the Select Committee, see supra note 9, introduced S. 804, a proposal based on the Select Committee's findings. The bill stated that no undercover operation should be 
the session.

The entrapment debate has focused on whether current doctrine, the so-called subjective approach, should be maintained, or whether the objective approach, endorsed by a minority of the Supreme Court, ${ }^{11}$ many scholarly commentators, ${ }^{12}$ and a handful of state courts, ${ }^{13}$ should be adopted in its stead. ${ }^{14}$ The critical distinction between the subjective

initiated, maintained, or expanded in the absence of reasonable suspicion and required specificity with regard to the target and the alleged ongoing criminality. Findings of reasonable suspicion were to be made by an Undercover Operations Review Committee within the Department of Justice or, in certain circumstances, by the head of the field office in charge. Failure to comply with the reasonable-suspicion requirement would neither be available as a defense in a criminal prosecution nor provide a basis for a civil action against the government. Finally, the bill adopted the objective approach to the entrapment defense. See S. 804, 98th Cong., 1st Sess., 129 CoNg. Rec. S2797-2801 (daily ed. Mar. 14, 1983).

11 The members of the Supreme Court adhering to the objective approach include Justices Roberts, Brandeis, and Stone, concurring in Sorrells v. United States, 287 U.S. 435 (1932); Justices Frankfurter, Douglas, Harlan, and Brennan, concurring in Sherman v. United States, 356 U.S. 369 (1958); and Justices Stewart, Marshall, and Brennan (again), dissenting in United States v. Russell, 411 U.S. 423 (1973), and United States v. Hampton, 425 U.S. 484 (1976).

12 See, e.g., Donnelly, Judicial Control of Informants, Spies, Stool Pigeons, and Agent Provocateurs, 60 YALE L.J. 1091, 1114 (1951); Goldstein, For Harold Lasswell: Some Reflections on Human Dignity, Entrapment, Informed Consent, and the Plea Bargain, 84 YALE L.J. 683, 687-90 (1975); Rotenberg, The Police Detection Practice of Encouragement, 49 VA. L. REv. 871, 899-903 (1963). The objective approach has been endorsed by the Select Committee, see SELECT Commitree REPORT, supra note 6 , at 371 , and was incorporated in S. 804, supra note 10 . The objective approach has also been endorsed by the American Law Institute in its Model Penal Code. See infra note 116.

13 The supreme courts of Alaska, Iowa, and Michigan have adopted an objective test. See Grossman v. State, 457 P.2d 226, 230 (Alaska 1969); State v. Mullen, 216 N.W.2d 375, 382 (Iowa 1974); People v. Turner, 390 Mich. 7, 19-20, 210 N.W.2d 336, 342 (1973). Hawaii, North Dakota, and New Hampshire have adopted the objective test by statute. See 1972 Hawaii Sess. Laws act 9, § 237; N.D. CENT. CoDE § 12.1-05-11 (Supp. 1983); N.H. Rev. STAT. ANN. \& 626:5 (1974); see also Park, The Entrapment Controversy, 60 MINN. L. REv. 163, 168 n.16 (1976) (discussing state statutes).

14 Most writers focus on whether or not the traditional, "subjective" approach should be replaced by the "objective" test advanced by a minority of the Supreme Court. See, e.g., Park, supra note 13, at 165-66 (1976); Rotenberg, supra note 12, at 897-903 (1963). Others have fashioned new methods for dealing with government overreaching in undercover operations. See, e.g., Dix, Undercover Investigations and Police Rulemaking, 53 TEx. L. Rev. 203, 221, 223-24 (1975) (setting forth an omnibus proposal for improving undercover operations); Gershman, Abscam, the Judiciary, and the Ethics of Entrapment, 91 YALE L.J. 1565, 1587-88 (1982) (proposing a statute that would prohibit the use of entrapment techniques against anyone not reasonably suspected of crime and proscribe police methods that are unreasonable, that are taken in bad faith, or that cause or threaten substantial harm to individuals or society); Note, The Defense of Entrapment: A Plea for Constitutional Standards, 20 U. FLA. L. REv. 63, 67-68, 72-73, 80 (1967) (suggesting due process clause, privilege against selfincrimination, and fourth amendment as constitutional bases for the entrapment defense and recommending a test requiring probable cause prior to solicitation and reasonableness in execution) [hereinafter cited as Note, The Defense of Entrapment]; Note, The 
and objective formulations of the entrapment defense is the underlying policy purpose each purports to serve. The policy emphasized by the subjective approach is that innocent individuals should not be led into crime by the police. ${ }^{15}$ The objective approach is animated exclusively by a concern with whether or not the conduct of the police was acceptable. ${ }^{16}$ Of course, these policy goals are not mutually exclusive. What differentiates them is the subject on which they focus. The subjective view looks to the character of the individual defendant, while the objective view looks to the actions of law enforcement officers. ${ }^{17}$ These inquiries can yield identical ${ }^{18}$ or contrary ${ }^{19}$ results.

After a brief review of the facts of the DeLorean and Abscam cases, this Comment attempts to demonstrate that the subjective approach to entrapment is theoretically untenable because it is based on the rationale that the defendant, although induced to commit a crime by

Serpent Beguiled Me and I Did Eat: The Constitutional Status of the Entrapment Defense, 74 YALE L.J. 942, 953 (1965) (suggesting an alternative system in which "[t]he fact of a successful solicitation would not in itself give rise to criminal liability; it would only be relevant as evidence of an independently existing course of criminal conduct") [hereinafter cited as Note, The Serpent Beguiled Me]. One writer has concluded that, whatever analysis is applied, the entrapment defense is a "fundamentally erroneous doctrine." Seidman, The Supreme Court, Entrapment, and Our Criminal Justice Dilemma, 5 SUP. CT. REV. 111, 113 (1981) ("[E]ntrapment doctrine is one of a number of adaptive mechanisms which compensate for our failure to develop a coherent theory of blame and choice to regulate the imposition of criminal punishment.").

is See Rotenberg, supra note 12, at 898.

${ }^{16}$ See id. at 899.

17 The subjective view asks whether or not the defendant is an "otherwise innocent" individual, Sorrells v. United States, 287 U.S. 435, 448 (1932), who "was induced to commit [a crime] by the Government," United States v. Russell, 411 U.S. 423, 435 (1973). This approach endeavors to establish whether or not the defendant was "predisposed"-that is, whether the offered inducement merely provided a welcome opportunity to an existing criminal or created a new criminal. See, e.g., Russell, 411 U.S. at 429 . The objective approach is concerned with police impropriety, see Sherman v. United States, 356 U.S. 369, 380 (1958) (Frankfurter, J., concurring), and attempts to evaluate the investigating officer's conduct without inquiring into the defendant's state of mind, see Russell, 411 U.S. at 441 (Stewart, J., dissenting). The "objective" measure of police conduct is generally an inquiry into whether or not an "average lawabiding citizen" would have been lured into criminality by a similar inducement. See Park, supra note 13, at 173.

${ }_{18}$ See, e.g., Sherman v. United States, 356 U.S. 369 (1958). Sherman was a recovering heroin addict who met government informant Kalchinian in a doctor's office where both were seeking help for their narcotics habits. Kalchinian, feigning serious withdrawal symptoms, prevailed upon Sherman to secure some narcotics for him. Only after repeated pleadings did Sherman give in. The majority held that he was an otherwise innocent individual who was not predisposed to crime. See id. at 373 . The concurring minority, per Justice Frankfurter, stated that the impropriety of the informant's action barred prosecution of the case. See id. at 383 (Frankfurter, J., concurring).

19 See, e.g., United States v. Russell, 411 U.S. 423 (1973). The Court applied the subjective test and held that there had been no entrapment. See id. at 429,436 . The dissenters would have found entrapment based on an application of the objective test. See id. at 438-39 (Douglas, J., dissenting); id. at 441-47 (Stewart, J., dissenting). 
government officials, is "otherwise innocent." The Comment argues that identifying and curbing undesirable police conduct is the only sound goal of the entrapment defense. The objective approach does not accomplish this goal because it presupposes a universal standard of morality by which it measures the reactions of suspects. A proper approach would define a permissible standard of conduct by which to measure police behavior.

The use of encouragement tactics by undercover agents can pose grave threats to individual privacy and integrity. ${ }^{20}$ At the same time, it is clear that as long as the federal government continues to prosecute victimless or consensual crimes, such as bribery, gambling, or narcotics trafficking, law enforcement authorities must be allowed to use undercover tactics. ${ }^{21}$ In order to balance individual rights and liberties with legitimate law enforcement objectives, Congress should limit the use of inducement techniques to situations in which they can be fully justified. This Comment argues that police encouragement tactics should be allowed only when law enforcement officials can demonstrate reasonable suspicion that the suspect is involved in ongoing criminal activity. Further, the Comment proposes that entrapment operations be subject to a warrant requirement, and that a warrant be issued only after a showing of reasonable suspicion. Compliance with the warrant, as well as the basis for its issuance, would be evaluated in a pretrial motion, and the defense of entrapment would be abolished.

\section{SOME ANEcDotal BACKground}

\section{A. John Z. DeLorean}

According to newspaper accounts of the DeLorean trial, by 1980

${ }^{20}$ See Dix, supra note 14, at 211-12 (asserting that undercover operations have an impact on the individual's sense of personal privacy, privacy in interpersonal relationships, and the individual's first amendment interest in freedom of association); see also S. 804, supra note 10, at S2798 (requiring "probable cause [rather than reasonable suspicion] to believe that the [undercover] operation is necessary to detect or prevent specific acts of criminality" if the operation involves (1) infiltration of a political, governmental, religious, or news organization, or (2) impersonation of an attorney, physician, clergyman, or newsperson, and "there is a significant risk that another individual will enter into a confidential relationship with that person").

${ }^{21}$ See Select Commirtee RePort, supra note 6, at 11 (stating that because "organized crime and consensual crimes such as narcotics trafficking, fencing of stolen property, and political corruption" are the main challenges of law enforcement today, and because criminals are "increasingly powerful and sophisticated . . ., some use of the undercover technique is indispensable to the achievement of effective law enforcement"). But see EDWARDS COMMITTEE REPORT, supra note 6, at 10 ("not at all clear that comparable resources devoted to traditional, reactive investigatory methods would not be as effective as the undercover techniques" in curbing consensual crimes). 
the DeLorean Motor Company was in dire financial straits. ${ }^{22}$ John $\mathrm{Z}$. DeLorean, the company's chairman, desperately needed ten million dollars in order to salvage the company. ${ }^{23}$ Around this time, former neighbor and occasional narcotics dealer James Timothy Hoffman got in touch with DeLorean and invited him to participate in a major cocaine transaction. ${ }^{24}$ Hoffman, an admitted perjurer ${ }^{25}$ who had been working as an FBI informant for some time prior to the DeLorean incident, ${ }^{26}$ said that DeLorean was the first to raise the subject of drugs: DeLorean wanted to make money quickly in a big narcotics deal and hoped that Hoffman would be able to arrange something. ${ }^{27}$ Before Hoffman came forward with his allegations, the FBI had no reason to believe that DeLorean was involved in the drug scene in any way. ${ }^{28}$

The original scenario devised by the participants in the cocaine transaction was the following: DeLorean would invest two million dollars toward the purchase of the cocaine and would make as much as sixty million dollars in profit from its resale. ${ }^{28}$ This arrangement became unworkable, however, when DeLorean revealed that he would have to withdraw from the operation due to his inability to raise the two million dollars. ${ }^{30}$ At this time, either FBI agent Benedict Tisa ${ }^{31}$ or Hoffman ${ }^{32}$ offered an alternative. Under the new proposal, DeLorean simply had to put up two million dollars worth of collateral, which included several sports cars, spare parts, and other property. ${ }^{33}$ DeLorean also signed over the entire voting stock of DeLorean Motor Company, Inc., to the federal agents who were posing as drug deal-

22 See Cummings, Drug Talk in 1980 Laid to DeLorean, N.Y. Times, May 19, 1984, at A6, col. 1.

${ }_{23}$ See Cummings, Tapes Depict DeLorean as Eager for Drug Deal, N.Y. Times, Apr. 25, 1984, at A16, col. 4.

${ }_{34}$ See Cummings, supra note 22; Cummings, Witness Uncertain DeLorean Intended Drug Deal, N.Y. Times, May 5, 1984, at A18, col. 4.

${ }^{25}$ See Taylor, Feds Run Into an Entrapment Backlash, N.Y. Times, Aug. 19, $1984, \S 4$, at 2 , col. 3 .

${ }_{28}$ See Cummings, supra note 22.

27 See id.

${ }^{28}$ See Official Says DeLorean Wasn't Suspect at First, N.Y. Times, Mar. 31, 1984 , at A6, col. 6.

${ }_{29}$ See Cummings, Defense Cites DeLorean's "Fear" of Drug Dealers, N.Y. Times, July 4, 1984, at A7, col. 1. DeLorean was ultimately indicted for conspiracy to distribute fifty-five pounds of cocaine with a street value of $\$ 24$ million. See Cummings, Agent Admits Financing Plan Kept DeLorean in Drug Deal, N.Y. Times, May 12, 1984, at A29, col. 1.

so See Cummings, Agent Admits Financing Plan Kept DeLorean in Drug Deal, N.Y. Times, May 12, 1984, at A29, col. 1.

s1 See id.

32 See Cummings, Prosecutor's Role in Inquiry on DeLorean Is Questioned, N.Y. Times, July 18, 1984, at A15, col. 4.

ss See Cummings, supra note 30. 
ers. $^{34}$ Finally, Tisa recommended that DeLorean be sure to launder any profits from the transaction through one of his companies. ${ }^{35}$

The jury had little trouble acquitting DeLorean. ${ }^{36}$ Interviews with several jurors after the trial indicated that the acquittal was based both on disapproval of the government's tactics in its investigation of DeLorean and on the conclusion that the government had failed to prove that DeLorean had committed a crime. ${ }^{37}$ Because DeLorean was prosecuted in federal court, the judge instructed the jury to evaluate the entrapment defense in accordance with the subjective view. ${ }^{38}$ However, it seems from the jurors' remarks that they followed the objective approach instead. ${ }^{38}$ Those jurors who discussed the entrapment issue with reporters emphasized the impropriety of the operation, not DeLorean's character. ${ }^{40}$

One juror expressed the view that the FBI went after DeLorean only because he was an influential person. ${ }^{41}$ There were several indications that the agents viewed DeLorean as a highly desirable arrest. One agent referred to DeLorean as his "meal ticket."42 Hoffman boasted to anxious agents two months before DeLorean's arrest that he was "going to get [DeLorean] for you guys."43 Tisa testified that the FBI agents intended to arrest DeLorean when the cocaine was delivered regardless of how he reacted-unless, of course, his response was to call the Drug Enforcement Agency or the FBI. ${ }^{44}$ It was undoubtedly the spirit of the hunt that led Tisa to report to FBI headquarters that DeLorean was "involved in large scale narcotics transactions, in addition to the laundering . . . of large amounts of illegally received in-

s4 See Cummings, Defense Cites DeLorean's "Fear" of Drug Dealers, N.Y. Times, July 4, 1984, at A7, col. 1 .

ss See Cummings, Agent Says He Opened DeLorean Drug Talks, N.Y. Times, Apr. 28, 1984, at A24, col. 1 .

so See Lindsey, Jurors Cite Entrapment and Failure to Prove Case, N.Y. Times, Aug. 17, 1984, at A1, col. 3. Although the deliberations lasted for twenty-nine hours, the jury reached the verdict with only a single vote on each count. See id.

37 See id.

so See Kendall, "It's All in God's Hand," Los Angeles Times, Aug. 9, 1984, § 2, at 1 , col. 1 .

s9 See Lindsey, DeLorean Jurors Discuss Reasons Behind Verdict, N.Y. Times, Aug. 18, 1984, at A46, col. 1.

${ }^{10}$ See id.

41 See id. col. 6.

${ }^{12}$ Defense Presses Agent in DeLorean Case, N.Y. Times, June 23, 1984, at A6,

is Cummings, DeLorean Informer's Remark Is Trial Issue, N.Y. Times, Aug. 2, 1984, at A14, col. 4.

14 See Cummings, Agent Tells of Plan to Arrest DeLorean with Drugs, N.Y. Times, May 4, 1984, at A12, col. 4. 
come," 45 although he knew it wasn't true. His explanation for this message? "I thought it sounded pretty good."46

\section{B. Political Corruption: Abscam}

In the winter of 1980 , America was shocked by the news that six United States Congressmen, one United States Senator, a United States Immigration Service official, three members of the Philadelphia City Council, the mayor of Camden, New Jersey, and assorted bagmen, middlemen, and corrupt lawyers had been duped by an elaborate FBI operation called Abscam. ${ }^{47}$ Under the cover of Abdul Enterprises, Ltd., FBI agent Anthony Amoroso ${ }^{48}$ and informant Melvin Weinberg, a convicted confidence man, ${ }^{49}$ posed as frontmen for a fictional pair of wealthy Arab sheiks interested in making certain investments and securing certain favors. ${ }^{60}$ The Abscam defendants demonstrated that they were amenable to selling their offices in order to do business with the sheiks. Some were zealous and some were hesitant, but all were on videotape.

Between 1978 and 1980, Abscam went through several stages. It began as a standard sting operation ${ }^{51}$ to recover stolen art and securities. ${ }^{\text {52 }}$ In 1978, its focus shifted to political corruption in the New Jersey area. ${ }^{\text {ss }}$ By 1979 , the Abscam operatives had turned their atten-

48 Id.

48 Id.

47 See Maitland, supra note 1.

48 See United States v. Kelly, 707 F.2d 1460, 1462 (D.C. Cir.), cert. denied, 104 S. Ct. 264 (1983). Although Weinberg was involved in Abscam from its inception, Amoroso did not join until 1979, when he assumed the role of president of Abdul Enterprises. See id.

49 See United States v. Myers, 692 F.2d 823, 829 (2d Cir. 1982), cert. denied, 461 U.S. 961 (1983).

${ }^{s 0}$ See United States v. Kelly, 707 F.2d 1460, 1461 (D.C. Cir.), cert. denied, 104

S. Ct. 264 (1983).

52 "Stings" are far less complex than the operations on which this Comment focuses. In setting up a sting, undercover operatives develop a front for a supposedly illegal enterprise, such as a fencing operation, and leak the news that there is an illegal enterprise operating in the neighborhood. The agents then wait for interested parties to arrive. No inducement or encouragement is required, and the very arrival of the parties indicates their guilt. See Hearings, supra note 9, at 958-59 (statement of Jerry J. Berman, Legislative Counsel, American Civil Liberties Union). Although stings do not raise many of the concerns implicated by the more sophisticated entrapment techniques, they do, at the very least, involve the expenditure of scarce resources. For that reason alone, stings should be initiated only when there is reasonable suspicion of ongoing criminality of a particular kind in the targeted locality. See, e.g., infra note 178 and accompanying text.

${ }_{52}$ See United States v. Myers, 692 F.2d 823, 829 (2d Cir. 1982), cert. denied, 461 U.S. 961 (1983).

ss See Hearings, supra note 9, at 961 (testimony of Jerry J. Berman, Legislative 
tion to the "Asylum Scenario," wherein members of Congress promised to introduce private immigration bills for the sheiks in exchange for

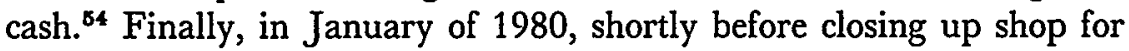
good, Weinberg applied his talents to the exposure of corruption in the municipal government of Philadelphia. ${ }^{\mathrm{ss}}$

The reason for the shift from stolen property to corruption in New Jersey politics is not entirely clear. One version of the story is that one of Abdul Enterprises' contacts from the first phase of Abscam confided to the undercover agents that there were politicians for sale in New Jersey, notably Mayor Angelo Errichetti of Camden. ${ }^{56}$ However, there is also evidence indicating that Weinberg had been looking into the political corruption question on his own before he received this tip. ${ }^{57}$ According to one court's account, Errichetti appeared at the door of Abdul Enterprises during the initial stage of Abscam and boasted to the sheiks' men of his influence and expertise with respect to casinos, narcotics, and the mob. ${ }^{.8}$

It is not clear whether Weinberg or Amoroso ${ }^{68}$ was the creative genius behind the Asylum Scenario. ${ }^{60}$ One day in Florida aboard the yacht of his supposed employers, Amoroso discussed with Errichetti the potential difficulties for the sheiks should a revolution, like those that befell Nicaraguan President Anastasio Somoza and the Shah of Iran, occur in their country. ${ }^{61}$ The solution, of course, would be to secure permanent resident alien status for the sheiks. The affable mayor assured Amoroso that he could secure the aid of influential public offi-

Counsel, American Civil Liberties Union).

st See id. at 964.

os See United States v. Jannotti, 673 F.2d 578, 581 (3d Cir.) (en banc), cert. denied, 457 U.S. 1106 (1982).

so See Hearings, supra note 9, at 961 (testimony of Jerry J. Berman, Legislative Counsel, American Civil Liberties Union).

B7 See Hearings, supra note 9, at 166-67 (testimony of Francis M. Mullen, Jr., Executive Assistant Director, Federal Bureau of Investigation).

${ }_{88}$ See United States v. Myers, 692 F.2d 823, 829-30 (2d Cir. 1982), cert. denied, 461 U.S. 961 (1983).

so See United States v. Kelly, 707 F.2d 1460, 1463 n.12 (D.C. Cir.), cert. denied, 104 S. Gt. 264 (1983); United States v. Myers, 692 F.2d 823, 830 n.4 (2d Cir. 1982), cert. denied, 461 U.S. 961 (1983).

Bo The Asylum Scenario first went into action in July 1979. See United States v. Myers, 692 F.2d 823, 830 (2d Cir. 1982), cert. denied, 461 U.S. 961 (1983). It is very likely that the idea arose from a successful undercover operation that Amoroso and Weinberg had undertaken beginning in March of that year, when they met a corrupt immigration official who could make immigration problems disappear for the right price. See United States v. Alexandro, 675 F.2d 34, 36-39 (2d Cir. 1982), cert. denied, 459 U.S. 835 (1982).

61 See United States v. Kelly, 707 F.2d 1460, 1462-63 (D.C. Cir.), cert. denied, 104 S. Ct. 264 (1983); United States v. Myers, 692 F.2d 823, 830 n.4 (2d Cir. 1982), cert. denied, 103 S. Ct. 2437 (1983). 
cials who would use their influence on the sheiks' behalf. ${ }^{82}$ Through Errichetti and other middlemen, ${ }^{68}$ the Asylum Scenario successfully ensnared Congressmen Michael "Ozzie" Myers, ${ }^{64}$ Raymond Lederer, ${ }^{85}$ Frank Thompson, ${ }^{66}$ John Murphy, ${ }^{67}$ Richard Kelly, ${ }^{88}$ and John Jenrette, ${ }^{69}$ each of whom promised to introduce private relief legislation for the sheiks in exchange for $\$ 50,000$ or more. ${ }^{70}$

The fourth phase of Abscam was initiated shortly before Abdul Enterprises closed its doors forever. ${ }^{71}$ Turning his sights to the municipal government of Philadelphia, Weinberg contacted an associate from his earlier adventures and told him that the sheiks were "looking to build a hotel' in Philadelphia,"'72 and would need contacts among local officials. These contacts turned out to be members of the city council, who were asked to lobby their colleagues concerning the desirability of the sheiks' proposal. The venture had a double appeal for the Philadelphia defendants since it not only put money in their pockets, but promised considerable economic gain for the city as well..$^{73}$

Councilman Harry Jannotti seemed hesitant about accepting his

${ }_{62}$ See United States v. Kelly, 707 F.2d 1460, $1462-63$ (D.C. Gir.), cert. denied, 104 S. Ct. 264 (1983); United States v. Myers, 692 F.2d 823, 830 (2d Cir. 1982), cert. denied, 461 U.S. 961 (1983).

6s "The term 'middleman' refers to individuals who unwittingly act as intermediaries between the FBI and the principal targets of undercover investigations. Although informants, confidential sources, and cooperating sources in these operations may also act as intermediaries, they understand that they are working with the FBI." EDWARDS COMMITTEE REPORT, supra note 6, at 25.

44 See United States v. Myers, 692 F.2d 823, 830 (2d Cir. 1982), cert. denied, 461 U.S. 961 (1983).

os See id. at 831-32.

See id. at 832-33.

67 See United States v. Murphy, 715 F.2d 39 (2d Cir. 1983).

68 See United States v. Kelly, 707 F.2d 1460 (D.C. Cir.), cert. denied, 104 S. Ct. 264 (1983). The sheiks also intended to make investments in the districts of cooperative congressmen. See id. at 1465.

60 See United States v. Jenrette, 744 F.2d 817 (D.C. Cir. 1984).

${ }^{70}$ See also United States v. Williams, 705 F.2d 603 (2d Cir.) (while not involving the Asylum Scenario, the charges against Senator Harrison Williams arose from his promising to use his office to help secure government contracts for a mining venture-in which he had an interest-in exchange for the sheiks' agreeing to invest in, and subsequently agreeing to buy, the venture), cert. denied, $104 \mathrm{~S}$. Ct. 524 (1983).

71 The Abscam operation ended on February 2, 1980. See Select Commrttee REPORT, supra note 6 , at 312 .

72 United States v. Jannotti, 673 F.2d 578, 581 (3d Cir.) (en banc) (quoting a phone conversation between Weinberg and Howard Criden, a Philadelphia attorney, who had previously served as a middleman between the FBI and several congressmen), cert. denied, 457 U.S. 1106 (1982).

2s The sheik was to invest $\$ 150$ million in the city. See id. at 584 . It is not clear whether Jannotti and codefendant George Schwartz, former President of the Philadelphia City Council, were led to believe that Philadelphia would lose the project if they did not agree to take the bribe. See id. at 602-03. 
$\$ 10,000$ bribe: he repeatedly asked the FBI agents about the legitimacy of the project. ${ }^{74}$ Jannotti was assured that taking the money was essential to maintaining the good will of the sheiks. ${ }^{75}$ The sheiks considered it very important to make friends with the people they were doing business with, and the only way to do that was with money. This way of doing business might seem unusual to an American, admitted FBI agent Wald, but was nevertheless characteristic of the "Arab mind."76 Reassured, Jannotti took the money. ${ }^{77}$

The Abscam defendants were less fortunate than John DeLorean. In every Abscam case, the defendants were convicted by the juries, and every conviction was upheld on appeal. In both Councilman Jannotti's and Congressman Kelly's trials, the presiding judge dismissed the indictments after the jury's finding of guilt ${ }^{78}$ but was reversed by the appellate court. ${ }^{78}$ Most of the defendants appealed their convictions to the Supreme Court, but certiorari was denied in every instance. ${ }^{\mathbf{8 0}}$

\section{Current Doctrine}

\section{A. The Subjective Approach}

When the Supreme Court first recognized the entrapment defense in the landmark decision of Sorrells $v$. United States, ${ }^{81}$ the majority

74 See id. at 587-89. Jannotti's concern with legitimacy was with whether the project would be used for gambling; Schwartz's concern was whether it would be used for "immoral purposes." Id. at 601 .

${ }^{73}$ See id. at 588-89.

70 Id.

77 See id. at 589.

78 See United States v. Kelly, 539 F. Supp. 363 (D.D.C. 1982), rev'd, 707 F.2d 1460 (D.C. Cir.), cert. denied, 104 S. Ct. 264 (1983); United States v. Jannotti, 501 F. Supp. 1182 (E.D. Pa. 1980), rev'd, 673 F.2d 578 (3d Cir.) (en banc), cert. denied, 457 U.S. 1106 (1982).

78 See United States v. Kelly, 707 F.2d 1460, 1474 (D.C. Cir.), cert. denied, 104 S. Ct. 264 (1983); United States v. Jannotti, 673 F.2d 578, 611 (3d Cir.) (en banc), cert. denied, 457 U.S. 1106 (1982).

${ }^{80}$ See Ciuzio v. United States, 104 S. Ct. 1305 (1984), denying cert. to 718 F.2d 413 (D.C. Cir. 1983); Weisz v. United States, 104 S. Ct. 1285 (1984), denying cert. to 718 F.2d 413 (D.C. Cir. 1983) (Ciuzio was tried with Weisz); Thompson v. United States, 104 S. Ct. 702 (1984), denying cert. to 710 F.2d 915 (2d Cir. 1983); Williams v. United States, 104 S. Ct. 524, denying cert. to 705 F.2d 603 (2d Cir. 1983); Kelly v. United States, 104 S. Ct. 264, denying cert. to 707 F.2d 1460 (D.C. Cir. 1983); Myers v. United States, 461 U.S. 961 (1983), denying cert. to 692 F.2d 823 (2d Cir. 1982); Carpentier v. United States, 459 U.S. 1108 (1983), denying cert. to 689 F.2d 21 (2d Cir. 1982); Alexandro v. United States, 459 U.S. 835, denying cert. to 675 F.2d 34 (2d Cir. 1982); Jannotti v. United States, 457 U.S. 1106, denying cert. to 673 F.2d 578 (3d Cir. 1982) (en banc); Myers v. United States, 449 U.S. 956, denying cert. to 635 F.2d 932 (2d Cir. 1980).

81287 U.S. 435 (1932). In Sorrells, Martin, a prohibition agent, induced Sorrells to procure some whiskey for him. At first, Sorrells refused. But Martin, who had be- 
endorsed the subjective view of the doctrine. The Supreme Court reiterated its approval of the subjective approach in Sherman v. United States $^{\mathbf{8 2}}$ and, more recently, in United States $v$. Russell. ${ }^{83}$

The subjective approach inquires into the state of mind and character of the defendant in order to determine whether entrapment has occurred and condemns police practices only when they lead to the creation of "new" criminals. "[T]he controlling question [is] whether the defendant is a person otherwise innocent whom the Government is seeking to punish for an alleged offense which is the product of the creative activity of its own officials." 84

To determine whether the defendant is an "otherwise innocent" individual, a court must ascertain whether or not the defendant was "predisposed" to commit the crime. ${ }^{85}$ Entrapment will be found where "the officials of the Government . . . implant in the mind of an innocent person the disposition to commit the alleged offense and induce its commission in order that they may prosecute." ${ }^{\text {86 }}$ Police are not permitted to create crime or criminals, but such creation of crime is thought to be possible only in the case of the nondisposed. ${ }^{87}$ An offer that, when made to a nondisposed defendant, is considered impermissible police activity, is looked upon as one simulated opportunity in a series of many authentic ones when a predisposed defendant is involved. ${ }^{88}$

Thus, under the subjective approach, any defendant found to be predisposed will be convicted regardless of the excessiveness of the inducement, and any nondisposed defendant will be acquitted no matter how reasonable, objectively considered, the inducement may appear. ${ }^{89}$ Although both the predisposed and the nondisposed have been led into crime, the former is simply careless-an "unwary criminal"-while the

friended the defendant by telling him that they had been in the same division in the army during World War I, asked Sorrells three times to get the whiskey. Finally, Sorrells relented. Id. at 439-40.

82356 U.S. $369,372-73$ (1958). For recitation of the facts, see supra note 18.

83411 U.S. $423,428-33$ (1973).

84 Sorrells, 287 U.S. at 451.

8s See Sherman, 356 U.S. at 372-73; Sorrells, 287 U.S. at 451. Entrapment doctrine seeks to "avoid stimulating the commission of an offense by persons who in fact do not create a sufficient danger to society." Dix, supra note 14, at 246.

${ }^{86}$ Sorrells, 287 U.S. at 442.

87 Id. at 444-45. "'[D]ecoys may be used to entrap criminals, and to present opportunity to one intending or willing to commit crime. But decoys are not permissible to ensnare the innocent and law-abiding into the commission of crime." "Id. at 445 (quoting Newman v. United States, 299 F. 128, 131 (4th Cir. 1924)).

88 See Donnelly, supra note 12, at 1108 ; Seidman, supra note 14 , at 118 . One commentator has persuasively argued that "little basis exists for predicting how likely it is that such an offense would be committed if law enforcement personnel did not interfere." Dix, supra note 14, at 256.

${ }^{80}$ See Seidman, supra note 14 , at 115. 
latter is naive and entitled to protection-an "unwary innocent."

To prove its case, the prosecution must somehow demonstrate the defendant's predisposition at the time of the alleged inducement. ${ }^{91}$ One method is to demonstrate by the facts of the incident itself the defendant's "ready complaisance" to commit the offense. ${ }^{92}$ To show this, the prosecution need only point to the defendant's ready acceptance of the proposal, seeming knowledge of how to commit the crime, or any information that might have been revealed in the midst of the transaction regarding the defendant's criminal propensities. ${ }^{93}$

Although this approach may not seem problematic at first, it is fatally circular. For, to have any logic at all, the predisposition inquiry must depend on the defendant's state of mind prior to the offense. It is hard to see how the defendant's behavior in the course of committing the crime advances this inquiry. Unless the defendant has been physically coerced into accepting the inducement, it is a mere form of words to assert that there was no disposition to err at the very time the criminal design was consummated. ${ }^{94}$ Knowledge of how to commit the crime

so Sherman, 356 U.S. at 372.

91 Once the entrapment defense has been raised, the burden of production is on the defendant, who must show that the crime was "induced" by a government agent or informant. Sagansky v. United States, 358 F.2d 195, 202-03 (1st Gir.), cert. denied, 385 U.S. 816 (1966). The prosecution then has the burden of proving beyond a reasonable doubt that the defendant was predisposed and "ready and willing [and] awaiting any propitious opportunity to commit the offence." United States v. Sherman, 200 F.2d 880, 882 (2d Cir. 1952), rev'd on other grounds, 356 U.S. 369 (1958); accord Sagan$s k y, 358$ F.2d at 202-03. The issue will then go to the jury for a factual determination. Although detractors of the subjective approach have been particularly critical of its assignment of the decisionmaking authority to the jury, Park has called entrapment " $a$ quintessential jury issue." Park, supra note 13, at 178.

92 See Sherman, 356 U.S. at 375; Park, supra note 13, at 183; Note, The Defense of Entrapment, supra note 14, at 78-79; see also United States v. Becker, 62 F.2d 1007,1008 (2d Cir. 1933) (opinion by Judge Learned Hand coining the phrase "ready complaisance").

${ }_{\text {gs }}$ See Park, supra note 13, at 248.

26 The predisposition inquiry varies from case to case and court to court. Some defendants are acquitted because they commit offenses only after showing much hesitation. See, e.g., Sherman, 356 U.S. at 373; Sorrells, 287 U.S. at 439-40. In other instances, the commission of the act is enough to show predisposition. Mr. Jannotti's repeated expressions of concern about the legitimacy of his transaction with the sheiks would seem to be enough to suggest a lack of "ready complaisance." See supra notes 74-77 and accompanying text. But neither the jury nor the appellate court were convinced. See United States v. Jannotti, 673 F.2d 578, 601-03 (3d Cir.) (en banc), cert. denied, 457 U.S. 1106 (1982). Courts are understandably loath to find a lack of "ready complaisance" where ambiguous behavior can be explained by an abundance of caution on the part of defendants. Several Abscam defendants relied on the use of ambiguous language to mask their knowledge of the illegality of their transactions. See, e.g., United States v. Myers, 692 F.2d 823, 844 (2d Cir. 1982) (Congressman Thompson's oblique comment-"You look after that for me will you?"- to attorney Criden in reference to the briefcase of money he received, signified not ignorance of the briefcase's contents, but a deliberate attempt by Thompson to mask his knowledge should his ac- 
and information about the defendant's criminal history are useful only in relation to past crimes; they do not indicate predisposition to commit the present crime. One commentator calls the inquiry into the defendant's state of mind at the time of the offense "evidentiary bootstrapping," cause he committed the act, and then is held responsible for the act because he was predisposed." $" 96$

The prosecutor may also try to prove predisposition by reference to the defendant's character. This technique raises what is perhaps the most persistent criticism of the subjective approach: its reliance on normally inadmissible evidence such as reputation, rumor, and criminal history, including prior arrests as well as convictions. ${ }^{97}$ This kind of evidence, which is usually considered unreliable and highly prejudicial, ${ }^{88}$ can chill the use of the entrapment defense by those who think that the risk of putting such information before the jury outweighs their

tion be discovered), cert. denied, 461 U.S. 961 (1983).

9s Gershman, supra note 14, at 1581.

so Id.

97 On evidence of reputation, see, for example, Rocha v. United States, 401 F.2d 529,530 (5th Cir. 1968) (reputation evidence held competent on issue of predisposition), cert. denied, 393 U.S. 1103 (1969). See also Park, supra note 13, at 213-14, 248-52 (federal courts have admitted otherwise inadmissible reputation evidence to refute entrapment defense). On evidence of criminal history, see, for example, Pulido v. United States, 425 F.2d 1391, 1393 (9th Cir. 1970) (arrest years before on narcotics charge admissible to show predisposition in narcotics case). At least one federal circuit court has held that the prior arrest must have been for a crime similar to the one charged in order to show that the defendant was predisposed to commit that crime. See De Jong v. United States, 381 F.2d 725, 726 (9th Cir. 1967) (arrest for burglary and drunkenness inadmissible to show predisposition in narcotics case); see also Russell, 411 U.S. at 443 (Stewart, J., dissenting) (entrapment test that depends on predisposition allows unreliable and highly prejudicial hearsay, suspicion, and rumor evidence to be introduced).

${ }^{98}$ Russell, 411 U.S. at 443 (Stewart, J., dissenting); Sorrells, 287 U.S. at 459 (Roberts, J., concurring). Under the Federal Rules of Evidence, evidence regarding the defendant's character and past bad acts is not admissible to prove the prosecution's case. FED. R. EvID. 404. Our legal system maintains this practice because it recognizes that

[t]he natural and inevitable tendency of the tribunal-whether judge or jury-is to give excessive weight to the vicious record of crime thus exhibited and either to allow it to bear too strongly on the present charge or to take the proof of it as justifying a condemnation, irrespective of the accused's guilt of the present charge.

1A J. Wigmore, Evidence in Trials at Common Law $\$ 58.2$ (Tillers rev. ed. 1983).

An exception to the rule on the admissibility of evidence of character and past bad acts occurs when the defendant introduces evidence of her own character. In this instance, the prosecutor is given the opportunity to rebut. FED. R. EvID. 404(a)(1). Because the theory of the subjective approach focuses on the "otherwise innocent" nature of the defendant, use of the entrapment defense implicitly raises the question of character. Therefore, it is consistent, strictly speaking, with the Federal Rules to allow the introduction of such evidence under the entrapment defense. 
chances of prevailing on the entrapment issue. The defendant may end up being judged not on the basis of the act for which the indictment was secured but for "a general criminal depravity and wickedness." The Supreme Court has dismissed this objection, however, stating that "if the defendant seeks acquittal by reason of entrapment he cannot complain of an appropriate and searching inquiry into his own conduct and predisposition as bearing on that issue. If . . . he suffers a disadvantage, he has brought it upon himself by reason of the nature of the defense." 100

Reliance on such evidence can lead to two laws of entrapment-one for those with no criminal history and good reputations, and another for defendants with bad reputations and prior records. Two defendants, "solicited at the same time in the same manner,"101 can receive different verdicts because of their different personal histories. Thus, the entrapment defense protects only the otherwise innocent who have had no prior contact with the law, thereby undermining a basic tenet of our criminal justice system-that "[p]ast crimes do not forever outlaw the criminal."

Furthermore, an approach that allows a finding of predisposition to be based on evidence of the defendant's past conduct takes a cynical view of "[ $t$ ]he whole ameliorative hopes of modern penology,"103 by assuming, "to the consternation of penologists, that the defendant has not been reformed."104 Thus, the concern that there is no way out of the criminal justice system once an individual gets into it is explicitly sanctioned by law, and the search for the "otherwise innocent" becomes a circumstantial rather than a moral inquiry.

Under the subjective approach to entrapment, the prevailing defendant is found innocent, even though all of the elements of the crime have been satisfied. ${ }^{105}$ There are other instances in our criminal law

92 Donnelly, supra note 12 , at 1108 .

100 Sorrells, 287 U.S. at 451-52.

101 Sherman, 356 U.S. at 383 (Frankfurter, J., concurring).

102 Id. Theoretically, this approach might enable a law enforcement officer to tempt with impunity an individual whose prior record and bad reputation were known to him, confident that such an individual would be unlikely to prevail on the entrapment defense. See Russell, 411 U.S. at 443-44 (Stewart, J., dissenting); Rotenberg, supra note 12 , at 898 .

10s Sherman, 356 U.S. at 383 (Frankfurter, J., concurring).

104 Rotenberg, supra note 12 , at 898.

105 Sorrells, 287 U.S. at 452. In Sorrells, the Court developed an implausible fiction to get around this problem: in the guise of statutory interpretation, the Court held that Congress did not intend government officials to enforce the prohibition statute under which Sorrells was indicted in a manner that would lure otherwise innocent people into committing crimes. See id. at 448-50. Justice Roberts considered this construction "strained and unwarranted." Id. at 456 (Roberts, J., concurring). 
where an individual who has satisfied all of the factual elements of a crime may be acquitted. Self-defense, duress, and necessity rest on the premise that the defendant has somehow been deprived of all choice and has no control over her actions. ${ }^{108}$ Similarly, the insanity defense is based on the premise that the defendant was incapable of making responsible or reasoned decisions, and thus could not form the intent necessary to be considered guilty of the crime. ${ }^{107}$ These exceptions to the normal rules of criminal responsibility seem to be premised on a notion that individuals can be held responsible only for actions taken voluntarily.

In the police encouragement situation, the individual's freedom to act is manipulated; her will and self-control are assaulted; she may feel driven to do things she will later regret. However, she has not been entirely deprived of choice or free will. When temptation comes, she can still say "NO!"108 When the weak-willed are manipulated into committing crimes by private individuals, they are not permitted to raise the entrapment defense. ${ }^{109}$ Consequently, it is reasonable to conclude that the only logical basis for the entrapment defense is the role of the police in the creation of the crime, rather than the belief that a defendant has been deprived of freedom of choice and is therefore innocent.

When the courts acquit defendants who are factually guilty, and who have been neither coerced nor deprived of their faculties in any tangible way, our whole system of guilt and innocence is thrown into question. If entrapment doctrine really relies on the innocence of the defendant rather than on the conduct of the police officer, the theory of acquitting those who are factually guilty but "otherwise innocent" arguably should extend further. For example, it might be extended to excuse those individuals who commit property crimes as a response to poverty. These individuals have been hurt by the economic system, and prior to engaging in crime they were "otherwise innocent." Their guilt is attributable to their circumstances. Furthermore, unless one subscribes to a theory of inherent criminality, almost any first offender is 391-92.

${ }^{108}$ See W. LAFAve \& A. Scotr, supra note $3, \S \S 49-50,53$, at $374-75,381-83$,

${ }_{107}$ See id. $\S 36$ at 268-71. The insanity defense, which if successful results in the commitment of the defendant to a mental institution, is also based on a desire to provide special treatment for certain criminal defendants. Thus, the result of a successful insanity defense is different from that of a successful plea of self-defense. Id.

108 But $c f$. infra notes 140-42 and accompanying text (ability to refuse temptation does not protect privacy or reputation).

108 See Russell, 411 U.S. at 442 (Stewart, J., dissenting); see also Park, supra note 13, at 240-43 (explaining and justifying the "private-person exception to the entrapment defense"). 
"otherwise innocent" before breaking the law.

Because of the difficulties involved in any attempt to give substance to the concept of the "otherwise innocent," it is an extremely shaky foundation on which to rest the entrapment defense. The method of determining the defendant's state of mind pursuant to this doctrine is tenuous, circular, and unfair. The inquiry into the defendant's "ready complaisance" seems to ensure a finding of predisposition whenever the crime is committed without prolonged hesitation. The use of character evidence to prove predisposition presents problems of prejudice and creates two laws of entrapment, one for those with criminal records and one for those with clean slates. For these reasons, the subjective view of entrapment is unsound in theory and unfair in practice. The focus on the defendant's character is misplaced and should be abandoned in favor of a test that is concerned with police practices.

\section{B. The Objective Approach}

Police misconduct in undercover operations is the focus of the objective view of the entrapment defense. The objective approach was articulated in the concurring opinions of Justice Roberts in Sorrells ${ }^{110}$ and Justice Frankfurter in Sherman. ${ }^{111}$ Both Frankfurter and Roberts rejected the majority's reliance on a defendant's predisposition as a method of defining and limiting impermissible entrapment techniques. Instead, they spoke of executive lawlessness and judicial integrity. Roberts deplored the idea of a court's defiling "the purity of its own temple" by opening its doors to "such prostitution of the criminal law."112 Frankfurter was particularly critical of the use of prejudicial evidence to establish predisposition. He argued that "[n]o matter what the defendant's past record and present inclinations to criminality, or the depths to which he has sunk in the estimation of society, certain police conduct to ensnare him into further crime is not to be tolerated by an advanced society." "113

Neither concurrence set down clear rules about how an objective entrapment defense might work. Roberts' view, which has not gained wide acceptance even among adherents of the objective approach, was that the issue of entrapment can be raised by the defendant or the judge (since it is the sanctity of the judicial temple that is being compromised)

${ }^{110}$ Sorrells, 287 U.S. at 453-59 (Roberts, J., concurring).

111 Sherman, 356 U.S. at 378-85 (Frankfurter, J., concurring).

112 Sorrells, 287 U.S. at 457 (Roberts, J., concurring).

113 Sherman, 356 U.S. at 382-83 (Frankfurter, J., concurring). 
at any point in the proceedings. ${ }^{114}$ Frankfurter adhered to the more orthodox view of treating the entrapment issue exclusively as a defense, but he did not subscribe to the pretense that the defendant is actually innocent. 115

Although Frankfurter did not lay down a clear rule, a portion of his opinion has been adopted as the standard formulation for what courts and commentators have come to call the "hypothetical person" approach. Encouragement tactics are permissible, in Frankfurter's view, as long as they are not "likely to induce . . the commission of crime ... [by] persons ... who would normally avoid crime and through self-struggle resist ordinary temptation. ... [The court should focus on] the likelihood, objectively considered, that it would entrap only those ready and willing to commit crime."116

The hypothetical-person standard is closely related to the tort law concept of the reasonable person. ${ }^{117}$ The reasonable person standard measures the conduct and reactions of the defendant against those of an imaginary reasonable person. ${ }^{118}$ Under the hypothetical-person standard, a court "objectively" evaluates the propriety of police conduct by asking what the average law-abiding citizen would have done under the

114 See Sorrells, 287 U.S. at 457 (Roberts, J., concurring); see also Rotenberg, supra note 12, at 902 (arguing that the trial and appellate courts, as well as the defendant, should be able to raise the entrapment issue).

115 See Sherman, 356 U.S. at 380 (Frankfurter, J., concurring).

116 Id. at 384. For a critique of Frankfurter's opinion, see Goldstein, supra note 12 , at 689-90. For an institutional adoption of Frankfurter's approach, see MODEL PENAL Code $\S 2.13(1)$ (b) (1962). The supporters of the subjective approach point to the anomalous results likely to occur under an application of the hypothetical-person doctrine. They argue that "nondisposed" defendants will be convicted when police inducements are deemed appropriate, while "predisposed" defendants will be acquitted because police activities were impermissible. See Park, supra note 13, at 216-17. Advocates of the objective approach respond that it is an acceptable compromise to let criminals go free because the constable blundered. Procedurally, the subjective and objective approaches differ in that the latter generally does not permit the admission of "prejudicial" evidence. But see id. at 201-09 (arguing that evidence of predisposition bearing on the propriety of police conduct should be admitted under the hypotheticalperson standard and finding that several jurisdictions support admitting such evidence). The most important procedural difference between the two approaches is that the objective approach leaves the decisionmaking authority in the hands of the judge so that proper standards for police encouragement techniques can be developed. See id. at 268 . $B u t c f . i d$. at $269-70$ (noting with respect to the objective approach the advantages of allowing the jury to decide the entrapment issue).

${ }^{117}$ See, e.g., W. Keeton, D. Dobbs, R. Keeton \& D. OWen, Prosser and KeEton: ON THE LAW of ToRTs 173-75 (5th ed. 1984) [hereinafter cited as Prosser \& KeETON]. Park compares the hypothetical person of the objective entrapment standard to the reasonable person of torts in order to support the allowance of predisposition evidence. He argues that in both cases one must endow the legal abstraction with some of the actual qualities of the defendant. See Park, supra note 13, at 204.

118 See Prosser \& KeEton, supra note 117, at 173-75; Restatement (SeCOND) OF TORTS $\S 283$ (1965). 
same circumstances. To say that this inquiry provides an objective measure of police practices is sheer pretense. By focusing on the defendant, the hypothetical-person standard gauges police conduct only in relation to the defendant's character or predisposition.

Because this minority approach requires the defendant to match the moral integrity and self-control of the hypothetical person, it neither objectively evaluates police tactics nor declines to consider the defendant's predisposition. ${ }^{119}$ By presupposing a universal behavioral norm, the hypothetical-person approach establishes criteria of morality by which to evaluate a defendant's reactions to police inducements, rather than independent standards by which to measure the legality of those inducements.

Indirectly, at least, the defendant's past and other situational factors will still be used to obtain a conviction under the objective approach. Persons with unsavory histories, inhabitants of certain environments, and people made desperate by some emotional, social, or economic crisis will arguably not meet the hypothetical standard of morality. Like the supersensitive or eggshell plaintiffs of tort law, ${ }^{\mathbf{1 2 0}}$ individuals unable to meet the hypothetical-person standard have a lower level of tolerance or endurance than the rest of us. We are not all made of the same hearty stuff, ${ }^{121}$ and it does not seem fair that we should be

110 Several commentators have pointed out the objective view's reliance on predisposition. See, e.g., Dix, supra note 14, at 254 ("Even under the minority 'objective' test, predisposition is quintessential; whether the methods used invoke entrapment depends upon whether they create a substantial risk that an offense would be committed by persons hypothetically reasonable and unpredisposed."); Goldstein, supra note 12, at 690 ("Frankfurter's opinion tends to blur the focus on the conduct of authorities by apparently restoring some relevance to making a distinction, however indistinct, between criminally and non-criminally prone citizens. He thus reintroduces the very element which formed the basis of his challenge to the majority of the Court.") (footnote omitted); Park, supra note 13, at 245 ("[T] he only difference [between the objective standard and the subjective standard] is that the fact-finder is asked to consider the impact of an inducement upon an imaginary nondisposed person instead of a real defendant."); Seidman, supra note 14, at 120 ("[I]n most cases, both the objective and subjective approaches would permit an inducement, so long as the defendant is predisposed.").

${ }_{120}$ See Prosser \& KeEton, supra note 117, at 291-92 \& 292 n.97 (defendant liable for death of plaintiff with "eggshell skull" even though normal person would only have suffered a bump on the head) (citing Dulieu v. White, [1901] 2 K.B. 669, 679).

121 In certain instances, the hypothetical-person standard will take account of individual weakness. See Park, supra note 13, at 173-74. However, the weaknesses accounted for are likely to be only those of which the hypothetical person can be proud, like sentiment and sympathy. See, e.g., Sherman, 356 U.S. at 383-84 (Frankfurter, J., concurring); see also Seidman, supra note 14, at 122 (explaining Sherman and Sorrells under the hypothetical-person standard by arguing that an average person might respond to the sentimental pleas of an officer); cf. Sorrells, 287 U.S. at 441 (opinion espousing subjective standard mentions officer's appeal to sentiment). 
evaluated as if we were. Just because the defendant is more vulnerable to temptation than the average law-abiding citizen, it is not apparent that any legitimate purpose is served by subjecting that individual to a randomly administered morality test. In fact, one can argue that the weak are far more in need of protection from police encouragement than the strong. ${ }^{122}$

Even assuming that the hypothetical-person standard is a fair device for determining when the entrapment defense should prevail, how can we measure the fortitude of the average law-abiding citizen? Do we really know what this individual is capable of ${ }^{123}$ The new syndicated television program, "People Will Do Anything For Money,"124 raises serious questions about how strong a barrier human dignity can erect against human greed. Therefore, for both theoretical and practical reasons, it is better to focus the inquiry upon police misconduct.

\section{Police Misconduct}

If the entrapment defense has any justification in logic or public policy, its function must be to define the reach of permissible investigative activities and the limitations within which law enforcement officers may be allowed to induce the citizenry to commit illegal acts. Deterring police misconduct is a more logical and workable goal than the slippery goal of protecting the "otherwise innocent." Of course, the two policy goals are not mutually exclusive. The concern over the integrity of police practices in the entrapment area is grounded on the fear that such unrestrained activity will do more than just root out elusive criminals, that it will actually create crime and corrupt the innocent. At the same time, defendants will tend to look more like innocent victims if the police activity is objectively offensive. ${ }^{125}$

Several different areas of concern are included under the police misconduct rubric: judicial integrity, ${ }^{126}$ the perversion of law enforce-

122 Cf. Seidman, supra note 14 , at $135-36$ (arguing that in actuality average lawabiding citizens should be better able to resist police enticements).

${ }^{123} C f$. Rotenberg, supra note 12, at 900 (arguing that police would not be able to identify the degree of encouragement that would be resisted by law-abiding citizens but not by ready-and-willing criminals).

124 "Anything for Money" (Paramount Television Domestic Productions 1985; Fred Travelena, host) ("Once again we've taken our cameras out into the field to see how much it would take to involve people in situations they would normally avoid.").

125 See, e.g., Sherman, 356 U.S. at 384 (Frankfurter, J., concurring).

${ }^{128}$ See Sorrells, 287 U.S. at 455, 457 (Roberts, J., concurring) ("[T]he preservation of the purity of its own temple belongs only to the court."); Casey v. United States, 276 U.S. 413, 425 (1928) (Brandeis, J., dissenting) ("This prosecution should be stopped ... [t]o preserve the purity of [the] courts."). 
ment, ${ }^{127}$ and the creation of crimes that would not have been committed otherwise $^{128}$ are a few of the predominant concerns. On a practical note, judges and commentators have complained about the waste of investigative resources that would be better devoted to the elimination of preexisting crime. ${ }^{129}$ Some commentators have expressed the concern that police inducement tactics are likely to be directed at disfavored groups ${ }^{130}$ or used for political reasons. ${ }^{131}$ Others share a distaste for random virtue tests conducted by the government. ${ }^{132}$ The more pessimistic observers of the human species harbor a fear that any one of us might not be strong enough to resist temptation or cynically believe that every one of us has a price. ${ }^{133}$ For those who still trust in the basic

127 See Sherman, 356 U.S. at 380 (Frankfurter, J., concurring) (condemning "enforcement of the law by lawless means"); Sorrells, 287 U.S. at 454, 457 (Roberts, J., concurring) (characterizing an entrapment scheme as a "revolting ... plan" and a "prostitution of the criminal law"), quoted in Russell, 411 U.S. at 439 (Douglas, J., dissenting); Casey v. United States, 276 U.S. 413, 425 (Brandeis, J., dissenting) (purpose of the entrapment defense should be to protect the government "from illegal conduct of the officers").

128 See EDwARDS CoMmitTeE REPORT, supra note 6, at 10 ("To the extent that the investigations involved created crimes, or 'scams,' a conviction obtained does not necessarily indicate that crime has been reduced, unless there is clear and convincing evidence that the individual convicted was in fact involved or about to be involved in the same criminal activity prior to the scam."); Dix, supra note 14, at 256 ("[L]ittle basis exists for predicting how likely it is that such an offense would be committed if law enforcement personnel did not interfere.").

${ }_{128}$ See, e.g., United States v. Kaminski, 703 F.2d 1004, 1010 (7th Cir. 1983) (Posner, J., concurring); United States v. Jannotti, 673 F.2d 578, 615 (3d Cir.) (en banc) (Aldisert, J., dissenting), cert. denied, 457 U.S. 1106 (1982); see also FBI Oversight: Hearings Before the Subcomm. on Civil and Constitutional Rights of the House Comm. on the Judiciary, 96th Cong., 1st \& 2d Sess. 139 (1980) (statement of Philip Heymann, Assistant Attorney General, Griminal Division, Department of Justice) ("We impose on ourselves the requirement that there be a well-founded suspicion of criminal activity in a sector or area before commencing an undercover operation . . . for the practical reason that [fishing expeditions] would be wasteful of our scarce investigative resources.").

130 See, e.g., Hearings, supra note 9, at 957 (testimony of Jerry J. Berman, Legislative Counsel, American Civil Liberties Union) (stating that "[w]ithout proper safeguards . . . undercover operations may involve . . . improper selective investigations"); Seidman, supra note 14, at 145 "'If the government can offer inducements that no one would refuse, it can pick and choose the persons who will obey the law. The risk that this power might be used to punish disfavored groups is obvious.") (footnote omitted).

131 See, e.g., Chevigny, A Rejoinder, 230 Nation 204-05 (1980) (discussing The Abscam Caper, 230 Nation 161 (1980)).

132 See, e.g., United States v. Kelly, 539 F. Supp. 363, 377 (D.D.C. 1982) ("I do not believe that testing virtue is a function of law enforcement."), rev'd on other grounds, 707 F.2d 1460 (D.C. Cir.), cert. denied, 104 S. Ct. 264 (1983); Hearings, supra note 9, at 957 (testimony of Jerry J. Berman, Legislative Counsel, American Civil Liberties Union) (Safeguards need to be imposed to keep the government from "testing the virtue of citizens in general.").

${ }^{133}$ See, e.g., Sherman, 356 U.S. at 384 (Frankfurter, J., concurring) ("Human nature is weak enough and sufficiently beset by temptations without government adding to them and generating crime."); Seidman, supra note 14, at 150 (claiming that the 
goodness of human nature, there is nevertheless a feeling that our privacy and personal integrity should not be invaded without good reason. ${ }^{134}$ This concern is particularly relevant when entrapment schemes involve the infiltration of friendships ${ }^{\mathbf{1 3 5}}$ and certain privileged relationships. ${ }^{138}$ Finally, for some observers, any aggressive undercover activity by law enforcement bespeaks the creation of a police state and must, therefore, be strenuously monitored. ${ }^{137}$

Perhaps the most troublesome consequence of a police encouragement program unrestrained by any kind of anterior justification is the impact of the scam on the target who is not only innocent of any crime before the fact, but who, by refusing the inducement, manages to remain uncompromised. The rights of these wary innocents ${ }^{138}$ cannot be

existence of the entrapment defense is necessitated by the widespread belief "that many of us would succumb to the temptation to which only some of us are daily subjected"). Senator Daniel Inouye, advocating support of Senator Harrison A. Williams, Jr., stated,

Instead of finding corruption, [Abscam] proved that perhaps all of us are ultimately corruptible. We must live with our weaknesses as human beings, each in our own way.

It is not, however, the business of the executive branch to test for weaknesses in any Member of Congress or to attempt to discover at what point the uncorrupt can be corrupted.

128 Cong. Rec. S1472 (daily ed. Mar. 3, 1982).

134 See, e.g., Note, The Defense of Entrapment, supra note 14, at 68 ("A citizen suffers a deprivation of . . . liberty both when he becomes the target of police seductions and when the state judicial machinery imposes criminal sanctions.").

${ }_{135}$ See United States v. White, 401 U.S. 745, 787 (1971) (Harlan, J., dissenting) ("The impact of . . . third-party bugging, must . . . be considered such as to undermine that confidence and sense of security in dealing with one another that is characteristic of individual relationships between citizens in a free society."); $c f$. Dix, supra note 14, at 211 n.9 (discussing the adverse effects of government infiltration on the relationships of members of "Vietnam Veterans Against the War").

1s8 Under The Attorney General's Guidelines on FBI Undercover Operations, reprinted in SELECT COMMITTEE REPORT, supra note 6, at 536, undercover operations in which agents or individuals working with the FBI pose as attorneys, physicians, or reporters can be authorized only by the Director of the FBI. See id. at 541-42. If an actual practitioner in such a privileged relationship comes forth to provide confidential information to the FBI, the FBI must notify the Assistant Attorney General in charge of the Criminal Division, discourage the individual from breaching the confidence, and accept the information only if serious consequences would result from rejection of the offer. See id. at 527.

${ }^{137}$ See United States v. Jannotti, 673 F.2d 578, 612-13 (3d Cir.) (en banc) (Aldisert, J., dissenting) (comparing the techniques of the FBI in Abscam to those of the Gestapo), cert. denied, 457 U.S. 1106 (1982); EDWARDS CoMMITTEE REPORT, supra note 6, at 77 (Indiscriminate targeting of subjects is "more the hallmark of a police state than a free society.").

${ }^{138}$ Cf. Sherman, 356 U.S. at 372 (distinguishing between traps for the unwary innocent and traps for the unwary criminal). The concern for protecting the rights of the innocent is manifested in other areas of criminal procedure. The state does, on occasion, arrest and prosecute individuals who are innocent of the crimes charged, just as the FBI sometimes attempts to induce crimes by individuals who do not succumb to 
vindicated by either of the mainstream entrapment doctrines. ${ }^{139}$ Two subjects of the Abscam operation who did not succumb to temptation continued to feel guilty, compromised, distrustful, and uncertain long after their names had been cleared. ${ }^{140}$ Thus, it is disingenuous to say that undercover inducements come with their own built-in protection and safeguard, the target's ability to say "NO!"141 Willpower may protect the wary innocents against the commission of crime, but it is no protection for their interest in psychic privacy ${ }^{\mathbf{1 4 2}}$ or unbesmirched repu-

the temptation. The difference is that in the trial and arrest contexts, procedural protections exist that prevent prosecution and arrest of any individual without good cause. Arrests are made pursuant to probable cause, see, e.g., Michigan v. DeFillippo, 443 U.S. 31, 36 (1979), and, in the federal system, felony prosecutions go forward pursuant to grand jury proceedings, see, e.g., Gaither v. United States, 413 F.2d 1061, 1066 (D.C. Cir. 1969), or preliminary hearings, see, e.g., Coleman v. Burnett, 477 F.2d 1187, 1198-1200 (D.C. Cir. 1973); FED. R. CRIM. P. 5.1(a). When these procedures are not followed, the individual has recourse to actions for malicious prosecution and false arrest. See, e.g., Dellums v. Powell, 566 F.2d 167, 191 n.65 (D.C. Cir. 1977) (malicious prosecution), cert. denied, 438 U.S. 916; id. at 175 (false arrest). Civil suits alleging violations of federal constitutional rights can be brought against state officials pursuant to 42 U.S.C. $§ 1983$ (1982), see Monroe v. Pape, 365 U.S. 167 (1961), and against federal officials directly under the United States Constitution, see Bivens v. Six Unknown Named Agents, 403 U.S. 388 (1971).

The approach advocated in this Comment would not preclude the use of inducement schemes that have innocent individuals as targets. It would merely provide innocent persons with the same procedural protection that they, and the guilty, are afforded in the context of orthodox criminal procedure.

${ }^{230}$ See Hearings, supra note 9, at 977-78 (testimony of Jerry J. Berman, Legislative Counsel, American Civil Liberties Union) (recognizing implicitly that the safeguards used by Abscam agents would not protect innocent individuals under either the subjective or objective standard).

140 Senator Pressler will carry this for life .... Hardly a day has gone by since I was named to [the Select] [C]ommittee that [he] has not at some point during the day on the floor come up and said something to me about: I hope that maybe I can finally be cleared. And I said to him: Larry, you are clear, there is no question .... But in his mind he was tainted.

Hearings, supra note 9, at 208 (statement of Sen. Rudman).

What is it, Bill Hughes, that you did or you said that would really have your name interjected into the scum of an ABSCAM? Can you tell me what I did or said at any time, what meetings I might have gone to, what people I might have talked to, what associations I might have had?

Hearings, supra note 9, at 956 (testimony of Jerry J. Berman, Legislative Counsel, American Civil Liberties Union) (quoting Congressman William Hughes).

${ }_{141}$ But see United States v. Myers, 527 F. Supp. 1206, 1225 (E.D.N.Y. 1981) (refusing to condemn the government conduct in Abscam as "outrageous" and thus violative of due process in part because the defendants "could simply have said 'no' to the offer") (citation omitted), affd, 692 F.2d 823 (2d Cir. 1982), cert. denied, 461 U.S. 961 (1983).

142 Other safeguards, such as requiring agents to make clear the illegal nature of the proposed activity or to model the activity as closely as possible on a realistic situation, also fail to protect the privacy interests of innocent individuals. See Hearings, supra note 9, at 960-61 (testimony of Jerry J. Berman, Legislative Counsel, American 
tation. These evils can be avoided through clarification and codification of threshold standards that must be met before any police encouragement operation can be initiated. Only then will "the inducement become[ ] a confirmation of criminality rather than a testing of virtue."143

\section{Reasonable SUSPICION}

\section{A. Anterior Justification}

In many instances, consensual crimes can be prosecuted only through the use of police encouragement. ${ }^{144}$ Because government officials must have flexibility in conducting such investigations, ${ }^{145}$ this Comment opposes per se rules aimed at prohibiting particular police practices deemed unsavory. ${ }^{146}$ Rather, the approach taken balances the competing concerns of law enforcement and civil liberties. The aim of this approach is the prevention, to the greatest degree possible, of the offering of inducements to the nondisposed, both the unwary and the wary innocents. ${ }^{147}$ Such prevention would serve the interests of the targeted person and, at the same time, enhance police efficiency: inducement techniques would be available only for use against suspects who truly pose a danger to society. ${ }^{148}$ Police encouragement practices should be limited by a requirement of reasonable suspicion of criminal involvement, ${ }^{148}$ determined prior to the initiation of the operation. ${ }^{180}$

Civil Liberties Union).

${ }^{143}$ Id. at 978.

144 See supra note 21.

145 See Select Committer RePort, supra note 6, at 388-89 (rejecting the warrant approach because of the delicacy and unpredictability of informant-government relationships and because of subtleties that do not inhere in the search context).

146 See infra notes 193-96 and accompanying text.

147 See Dix, supra note 14, at 249-50.

148 See id. at 219.

149 Probable cause would be too high a standard to require. If the officer could satisfy a level of probable cause to offer an inducement, there would most likely be probable cause to make an arrest. See EDWARDS COMMITTEE REPORT, supra note 6, at 113 (dissenting views) ("[A] probable cause standard would be the death knell to undercover operations."); $c f$. Dix, supra note 14, at 220 (arguing that a standard less stringent than probable cause should be adopted to enable police to obtain evidence to make arrests). "Reasonable suspicion," a somewhat lower standard of anterior justification, was advanced by the Supreme Court in Terry v. Ohio, 392 U.S. 1 (1968), to provide guidance to police when conducting a "stop and frisk." To justify a stop and frisk, the Court held, the officer must be able to cite "specific and articulable facts"-bare "hunches" would not suffice. Id. at 21-22. The officer would be expected to analyze concrete facts through the lens of professional experience. See id. at 21-22; see also The Attorney General's Guidelines on Griminal Investigations, reprinted in SELECT COMMITTEE REPORT, supra note 6, at 507 (describing "reasonable indication" " standard). But see FBI Undercover Operations: Hearings Before the Subcomm. on Civil and Constitutional Rights of the House Comm. on the Judiciary, 97th Cong., 2d Sess. 418 (1982) (testimony of William Webster, Director, FBI) ("What you have is a smell.").

150 The reasonable-suspicion standard has not fared well in the federal courts of 
Before offering a criminal inducement to a targeted individual, or setting up an operation creating an environment in which criminal activities will be encouraged, law enforcement officials should be required to demonstrate that they have reasonable suspicion that the target is presently involved in ongoing or incipient criminal activity or that such activity is taking place in the targeted locality. ${ }^{151}$ To ensure that such

appeals. In Heath v. United States, 169 F.2d 1007, 1010 (10th Cir. 1948), the Tenth Circuit held that reasonable suspicion is a necessary element of the government's proof. Heath was explicitly overruled on the reasonable-suspicion issue in United States v. Swets, 563 F.2d 989, 991 (10th Cir. 1977), cert. denied, 434 U.S. 1022 (1978). The Ninth Circuit has held that reasonable suspicion can overcome the defendants' claims of entrapment. Trice v. United States, 211 F.2d 513, 516 (9th Cir.), cert. denied, 348 U.S. 900 (1954). However, in United States v. Williams, 487 F.2d 210, 211 (9th Cir. 1973), cert. denied, 416 U.S. 958 (1974), the Ninth Circuit questioned the Trice court's requirement of reasonable suspicion. Williams held that Trice "did not require proof of reasonable suspicion to defeat the defense of entrapment." Id. (emphasis added).

On the other hand, the Sixth and Eighth Circuits' endorsements of the reasonablesuspicion standard have not been overruled or distinguished. See Morales v. United States, 260 F.2d 939, 940 (6th Cir. 1958) (entrapment found in part because the agents did not even have a reasonable suspicion that the defendant was engaged in illegal activity); C.M. Spring Drug Co. v. United States, 12 F.2d 852, 856 (8th Cir. 1926) (claim of entrapment defeated because of agents' reasonable suspicion of criminal involvement); see also Park, supra note 13, at $197 \mathrm{nn} .112-15$ (collecting cases and concluding that most circuits have rejected the reasonable-suspicion approach, which Park notes has declined in popularity since Russell); Case Comment, Due Process Defense When Government Agents Instigate and Abet Crime, 67 GEo. L.J. 1455, 1467 nn.98100 (1979) (collecting cases).

151 Many observers agree. See, e.g., Select Committee RePORT, supra note 6, at 377 ; Dix, supra note 14, at 257. As a response to Abscam, Attorney General Benjamin Civiletti promulgated guidelines for proper investigative procedures in undercover operations, which, although newly promulgated, had purportedly been in place during the Abscam operation. See The Attorney General's Guidelines on Criminal Investigations and Organizations, reprinted in SELECT COMMITTEE REPORT, supra note 6, at 504-16; The Attorney General's Guidelines on FBI Undercover Operations, reprinted in Select Commitree Report, supra note 6, at 536-55; The Attorney General's Guidelines on FBI Use of Informants and Confidential Sources, reprinted in SELECT COMMITTEE REPORT, supra note 6, at 517-30. The guidelines require that investigations be initiated only when "facts or circumstances . . . 'reasonably indicate' [that] a federal criminal violation has occurred, is occurring, or will occur." The Attorney General's Guidelines on Criminal Investigations of Individuals and Organizations, reprinted in SELECT CoMmITTEe RePORT, supra note 6, at 506. To insure that potential targets are protected from the investigative zeal of agents in the field, the guidelines set up an internal review structure to check that operations have prior justification. See The Attorney General's Guidelines on FBI Undercover Operations, reprinted in SELECT COMMTTTEE REPORT, supra note 6, at 538-48.

Implicit in the decision of the Department of Justice to promulgate investigative guidelines is the assumption that the guidelines will be followed by agents. However, recent experience refutes this supposition. See EDWARDS CoMmTTTEE REPORT, supra note 6, at 7 ("The record in [Operation Corkscrew, an investigation into case-fixing by the Cleveland judiciary] demonstrates that virtually every one of the principal safeguards was either directly violated, ignored, or administratively construed in a manner inconsistent with [its] stated purpose[] with profoundly disturbing results to the FBI, 
strictures are followed, investigators should be required to secure a warrant from a "neutral and detached magistrate"162 for the authorization of any inducement. ${ }^{153}$ The affidavit submitted to the magistrate by the investigating officer would have to allege: (1) the individual, category of individuals, locality, or institution ${ }^{\mathbf{1 5 4}}$ targeted; $^{\mathbf{3 5 5}}$ (2) the crime

the suspects, and the public."). In the DeLorean trial, federal drug agent John Valestra admitted backdating authorization documents for a pair of videotaping sessions two months after the fact. See Cummings, Agent in DeLorean Case Acknowledges Backdating of Documents, N.Y. Times, June 20,1984, at A17, col. 1. Asked why he did it, Valestra responded that he didn't want to "look bad" "and that "the form was a 'dumb' example of useless Government paperwork." Government Witness Admits Hiding Truth, N.Y. Times, June 21, 1984, at A16, col. 6. The unwillingness of agents to adhere to the guidelines and the inability of the FBI and the Department of Justice to enforce them underlines the advisability of a judicially enforceable warrant requirement.

152 Johnson v. United States, 333 U.S. 10, 14 (1948) (fourth amendment protection requires neutral and detached magistrate, not officers involved in "competitive enterprise of ferreting out crime," to decide whether to allow a search).

163 The interposition of the judiciary between the executive and the people is a traditional method for protecting civil liberties. Despite what has been said about the unmanageability of obtaining a warrant in the undercover context, see SELECT CoMMITTEE REPORT, supra note 6 , at 388 , and the danger of allowing the judiciary to interfere with executive functions, see Hearings, supra note 9, at 931 (statement of Kenneth R. Feinberg, Esq., Kaye, Scholer, Fierman, Hays \& Handler, Washington, D.C.), such a requirement is not unprecedented. As part of the Omnibus Crime Control and Safe Streets Act of 1968, Congress prohibited interception of oral or wire communications in general, but made an exception for law enforcement officials acting pursuant to a warrant. See Omnibus Crime Control and Safe Streets Act of 1968, Pub. L. No. 90-351, § 802, 82 Stat. 197, 213, 216-17, 218-21 (codified as amended at 18 U.S.C. $\$ \S 2511(1), 2516,2518$ (1982)). In addition, in 1978, Congress passed the Foreign Intelligence Surveillance Act, setting up a special court to consider warrant applications for surveillance operations involving foreign powers. See Foreign Intelligence Surveillance Act of 1978, Pub. L. No. 95-511, §§ 103-05, 92 Stat. 1783, 1788-93 (codified at 50 U.S.C. $\S \S 1803-05$ (1982)).

Some observers who have considered the feasibility of a warrant in the entrapment context reject the idea. See, e.g., SELECT COMMTrTEE REPORT, supra note 6, at 387-89 (opposition to undercover warrant legislation conditioned on belief that federal law enforcement agencies will be able to regulate themselves effectively); Hearings, supra note 9, at 931 (statement of Kenneth R. Feinberg, Esq., Kaye, Scholer, Fierman, Hays \& Handler, Washington, D.C.) (arguing that such a warrant would violate separationof-powers principles). Other observers favor the use of the warrant procedure. See EDWARDS COMMITTEE REPORT, supra note 6, at 10, 71-72 (recommending judicial warrant requirement "for ongoing and continuing undercover operations" because the internal review mechanism currently in place does not provide the independence of judgment and objectivity required to evaluate the sufficiency of the factual predicate); Wilson, The Real Issues in Abscam, Wash. Post, July 15, 1982, at A19, col. 2 (advocating prior judicial review when congressional figures are targeted to protect separation of powers); see also Hearings, supra note 9, at 996-1000 (testimony of Jerry J. Berman, Legislative Counsel, American Civil Liberties Union) (arguing for a warrant requirement but, as a politically feasible alternative, urging that the FBI adopt the internal review procedures outlined in the Undercover Operations Guidelines, as recommended by the Select Committee, see Select CommitTee Report, supra note 6, at $347-49$ ).

154 See Rotenberg, supra note 12 , at 875 n.16 (giving an example of institutional 
allegedly committed or about to be committed; ${ }^{156}$ (3) the grounds on which this belief is based and the reasons why those grounds are reliable; ${ }^{157}$ (4) an explanation of why the enforcement goal cannot be achieved through any less intrusive means, ${ }^{158}$ and (5) the structure of the proposed inducement. The structure requirement would demand a description of the agent's general plan of action and an assurance that the plan is as narrowly tailored as possible to achieve the permissible law enforcement goals described in the first two sections of the affidavit. ${ }^{18 \theta}$

Compliance with the warrant procedure could be raised by the defendant in a pretrial motion and evaluated in a pretrial hearing. ${ }^{160}$ If

crime).

${ }_{185}$ Cf. 18 U.S.C. $\S 2518(1)(b)(i v)$ (1982) (similar requirement for wiretapping). This requirement aims at preventing "fishing expeditions" among people not reasonably suspected of crime. It is a way of restraining agents and informants from operating on whims. See supra notes $138-43$ and accompanying text.

${ }_{156}$ Cf. 18 U.S.C. $\& 2518(1)(b)(i)$ (1982) (similar requirement for wiretapping). This requirement also protects against fishing expeditions.

157 This requirement is the heart of the application, because it forces an officer to set out the grounds for reasonable suspicion and allows an evaluation of the warrant application's persuasiveness. In this way, officers will be prevented from going ahead with mere "hunches" or "smell[s]." See supra note 149; see also Edwards CommITTEE REPORT, supra note 6, at 84 (recommending that warrant "application provide a full and complete statement of facts and circumstances relied upon").

188 Cf. 18 U.S.C. $\S 2518$ (1)(c) (1982) (similar requirement for wiretapping). Because of the impact of entrapment techniques on privacy interests, see supra note 20 , the large expenditure of resources required by many undercover operations, see supra note 129 and accompanying text, and the inability to be entirely certain that the subject would have committed the illegality without police encouragement, supra note 128, use of entrapment techniques should be limited to situations in which they are truly necessary. See also EDWARDS CoMmITTEE REPORT, supra note 6, at 84 (recommending that undercover operations "be used only upon a showing that normal investigations have been unsuccessful, or are unlikely to succeed, or constitute a danger to lives or property").

${ }^{180}$ Cf. 18 U.S.C. $\S 2518(1)$ (d) (1982) (limitation on duration of wiretap). This requirement aims at ensuring that the plan of action anticipated by the applying officer is justified by the grounds for suspicion, the target, and the potential crime. Otherwise, the officer might be able to get a warrant for one kind of operation and use it as a jumping-off point for entirely different projects. Although the Department of Justice Guidelines require, in lieu of a warrant, that authorization applications for undercover operations be submitted to supervisory personnel, see The Attorney General's Guidelines on FBI Undercover Operations, reprinted in SELECT CommitTeE REPORT, supra note 6, at 539-48, experience shows that the Guidelines are not always followed. The original Abscam operation, aimed at the recovery of stolen art and securities, was duly authorized by FBI Headquarters. Its subsequent shifts, however-first to the political scene in New Jersey and later to the United States Congress-were never reported or submitted for approval to a supervisory authority. See SELECT CoMMITTEE REPORT, supra note 6, at 16; see also supra note 151 (describing other instances in which agents neglected to follow procedural guidelines).

${ }_{160}$ Cf. 18 U.S.C. $\$ 2518(10)$ (a) (1982) (similar procedure for wiretapping). In Sorrells v. United States, 287 U.S. 435, 437-38 (1932), the government argued unsuccessfully that the defendant should raise any claim of entrapment in a pretrial motion. 
the inducement activity is found to have been justified and warranted, the hearing will be followed by an ordinary criminal trial. If the defendant prevails on the motion, there will be an absolute bar to prosecution. $^{1 \mathbf{1 6 1}}$ Thus, the claim of entrapment, like the claim of illegal search and seizure, will not form part of the defendant's case at trial.

On a procedural level, this approach will be an improvement over current practice. First, once it has been determined that setting the defendant at liberty is the appropriate sanction for inappropriate police solicitation, a bar to prosecution is more consistent with our criminal law and procedure than an acquittal. The defendant is set free not because of innocence but because public policy dictates that the state's misfeasance bars prosecution. ${ }^{\mathbf{1 6 2}}$ Second, the pretrial motion will be entertained by the judge, thereby keeping prejudicial information from the jury and ensuring that entrapment case law will be developed by the judiciary. Finally, the defendant will be spared the dilemma of admitting factual guilt in order to assert the defense of entrapment. ${ }^{163}$

The reasonable-suspicion inquiry required for issuance of the warrant improves on the test for predisposition under the current subjective approach to entrapment in two important respects. First, the inquiry will be conducted by a magistrate before the commencement of the undercover operation. Unless government officials can show that they reasonably suspect that the target is involved in ongoing criminal activities, and that it will be difficult to catch the suspect without undercover inducement, there will be no sting or scam at all. The antecedent judicial inquiry reduces the likelihood that overzealous agents will lure wary innocents into crime. Moreover, because the magistrate's reasonable-suspicion inquiry will be held prior to commencement of the operation, evidence of the target's ready complaisance in committing the offense will not be considered. ${ }^{164}$ The "evidentiary bootstrapping"16s that bedevils the present inquiry into predisposition will therefore be eliminated.

Second, the magistrate will consider evidence only of a current criminal career. Indications of recent criminal activity for which the subject has not been arrested or indicted would be particularly relevant, for it is just such activity that makes the target the appropriate subject

161 A proposal by the American Givil Liberties Union would also provide for civil damages to enforce the warrant requirement. See Hearings, supra note 9, at 999 (testimony of Jerry J. Berman, Legislative Counsel, American Civil Liberties Union).

${ }_{162}$ See Sherman v. United States, 411 U.S. 369, 380 (1958) (Frankfurter, J., concurring).

16s See W. LaFave \& A. ScotT, supra note $3, \S 48$, at 373.

164 See supra note 92 and accompanying text.

16s See supra note 95 and accompanying text. 
of a police encouragement operation. ${ }^{166}$ Information about the target's prior propensity for crime, such as allegations and reports of previous unindicted activities, arrests, or convictions, might be considered if it is sufficiently connected with the target's present criminal involvement. However, the mere fact of prior criminality would not suffice to establish reasonable suspicion. The proposed reasonable-suspicion inquiry is based on a recognition that past conduct in itself is not indicative of present criminal involvement, just as it is not a barometer for determining predisposition. ${ }^{\mathbf{1 6 7}}$ Because the reasonable-suspicion inquiry obviates reliance on evidence of the target's ready complaisance or past conduct, it is less circular, tenuous, and unfair than the inquiry into predisposition used under the present subjective approach to entrapment.

\section{B. Codifying the Warrant Requirement}

Although any statute codifying the principles described in this Comment would probably not be based directly on the fourth amendment, ${ }^{168}$ such a statute would nevertheless borrow heavily from fourth amendment jurisprudence both in its procedures, including the warrant requirement and the pretrial hearing, and in its concerns with anterior justification, ${ }^{169}$ flexibility, ${ }^{170}$ and reasonableness. ${ }^{171}$ Besides setting

${ }^{186}$ See Dix, supra note 14 , at 256-57.

167 See supra text accompanying notes 97-104.

108 See supra notes 8-10 and accompanying text. It is clear that the Supreme Court is becoming less receptive to claims of fourth amendment violations. See, e.g., United States v. Johns, 105 S. Ct. 881 (1985) (upholding a warrantless search of packages three days after they had been removed from vehicles that police had probable cause to believe contained contraband); New Jersey v. T.L.O., 105 S. Ct. 733 (1985) (upholding a school administrator's warrantless search of a high school student's purse on the grounds that the fourth amendment does not require school officials to obtain a warrant before searching a student and that searches of students by school officials are not subject to the probable cause requirement); $c$. Hoffa v. United States, 385 U.S. 293 (1966) (use of secret government informant not covered by the fourth amendment's protections against unreasonable searches and seizures). Thus, any reform in the entrapment area will have to come from Congress.

${ }_{168}$ See, e.g., Wong Sun v. United States, 371 U.S. 471, 479-82 (1963) (with or without warrant, arresting officer needs more than mere suspicion to make an arrest).

170 See, e.g., Gerstein v. Pugh, 420 U.S. 103, 113-14 (1975) (policeman's on-thescene assessment of probable cause provides legal justification for arresting a suspect); Coolidge v. New Hampshire, 403 U.S. 443, $465-71$ (1971) (police can seize items in "plain view" while executing a search warrant that names other objects).

171 See New Jersey v. T.L.O., 105 S. Ct. 733, 743 (1985) ("The fundamental command of the Fourth Amendment is that searches and seizures be reasonable ... ."); $c f$. Dix, supra note 14, at 294 (proposing that the Supreme Court adopt the view that "deception [by undercover agents] constitutes a 'search' within the meaning of the fourth amendment. This action would make the flexible concept of reasonableness available for development of the basic limitations on undercover investigations essential to the drawing of well-founded operational rules.") 
forth the procedural requirements of the warrant hearing and the pretrial motion, this statute should specify the contents of the affidavit upon which the warrant may be issued. ${ }^{172}$ It should also set forth guidelines for the magistrate conducting the reasonable-suspicion inquiry regarding the information that may be considered and the types of undercover methods that may be approved. The statute should contain examples of acceptable types of information and undercover methods but should set forth few, if any, per se rules. Rather, the magistrate should be permitted to conduct a flexible inquiry into the reasonableness of the proposed inducement. The following section outlines the kinds of information that a magistrate may reasonably consider at the warrant hearing and the kinds of methods that agents may reasonably employ in an undercover operation.

\section{Information Supporting Reasonable Suspicion}

The principal source of information providing the basis for reasonable suspicion will undoubtedly be informants or middlemen. The use of informants and middlemen in the $\mathrm{Abscam}^{173}$ and the DeLorean ${ }^{174}$ investigations demonstrates the importance of determining the reliability of such individuals. ${ }^{175} \mathrm{~A}$ magistrate should not depend on information obtained from these sources unless the investigating officer's affidavit demonstrates why the informants are credible. ${ }^{176}$ At a minimum, the

172 See supra text accompanying notes 155-59.

173 In Abscam, informant Melvin Weinberg and FBI agent Anthony Amoroso relied on a number of individual officials whom they knew to be corrupt to bring in public officials for bribe offers. These middlemen did not know that Weinberg and Amoroso were working for the FBI. They too were indicted and convicted along with their principals. See supra notes 63-70 and accompanying text.

${ }^{174}$ See Cummings, Agent Says He Opened DeLorean Drug Talks, N.Y. Times, Apr. 28, 1984, at 24, col. 1 .

${ }^{178}$ Middlemen Errichetti and Silvestri, who led the FBI to several of the Abscam subjects, did not even know several of the legislators they claimed to "own." SELECT Commitee RePoRT, supra note 6, at 68-77. In middleman Ciuzio's first meeting with Weinberg and Amoroso, he indicated that Congressman Richard Kelly was already taking money and was under Ciuzio's virtual control. Ciuzio's claims were false. See United States v. Kelly, 539 F. Supp. 363, 367 (D.D.C. 1982), rev'd on other grounds, 707 F.2d 1460 (D.C. Cir.), cert. denied, 104 S. Ct. 264 (1983). Nevertheless, "[i]n some cases, the FBI continued to rely on middlemen even after they had proved to be unreliable." Select Committee REPORT, supra note 6, at 19; see also EDwards COMMITTEE REPORT, supra note 6, at 58 ("[T] he record in [Operation] Corkscrew demonstrates an utter failure on the part of the [FBI] to do even rudimentary checking of [the middleman's] credibility or to seek confirmation of his assertions, even in the face of mounting evidence of his duplicity.").

${ }^{178}$ In developing standards for evaluating the credibility of informants, reference should be made to the test set out in Aguilar v. Texas, 378 U.S. 108 (1964), and explicated in Spinelli v. United States, 393 U.S. 410 (1969). In Aguilar, the Court held that an application by police for a search warrant on the grounds that they had "re- 
officer should be required to show how well the informant knew the target and how the informant obtained the relevant information. Whether the informant had some kind of track record would also be probative, as would the informant's reputation for trustworthiness. ${ }^{177}$

The police will also be able to rely on the usual variety of evidence used to support the initiation of investigations. For instance, a sting designed to trap dealers in stolen property would be justified by the disappearance of a great deal of property in a given locality or indications that such property was being sold in a certain locality. ${ }^{178}$ Scams designed to root out corruption in the administration of justice could rest in part on observations that justice is being dispensed in an irregular manner. ${ }^{179}$ Through police observation or community complaints there may be indications that a certain neighborhood is being flooded with narcotics. There may be a strange pattern in a city's contract assignments that gives rise to an inference of government corruption, ${ }^{\mathbf{1 8 0}}$ or a barrage of immigration bills introduced in Congress indicating that the process is being misused. ${ }^{181}$

ceived reliable information from a credible person," 378 U.S. at 109 (quoting the affidavit supporting the search warrant application), was insufficient to establish probable cause to justify the issuance of a search warrant. The Court held that a proper application must set forth the "underlying circumstances" surrounding (1) how the informant came across the information and (2) why the informant should be deemed credible. See $i d$. at 114. If these requirements could not be satisfied, a sufficient amount of accurate anecdotal detail, discoverable only to those in the know, might justify issuing a warrant on the basis of the tip. See Spinelli, 393 U.S. at 417-18.

The two-pronged Aguilar-Spinelli test was rejected, however, in Illinois v. Gates, 462 U.S. 213 (1983) (holding that the credibility of an informant's tip should be evaluated with reference to the totality of the circumstances). The proposal advocated in this Comment is consistent with the Gates standard: a careful consideration of the proffered information in light of the totality of the circumstances, buttressed by a dialogue with the informant as to the basis of the informant's knowledge, would be an appropriate degree of anterior justification. See also Hearings, supra note 9, at 551 (question by James F. Neal, Chief Counsel to the Select Committee) (suggesting that FBI agents question informants to determine credibility); $i d$. at 941 (question by Malcolm $\mathrm{E}$. Wheeler, Deputy Counsel to the Select Committee) (recommending a similar procedure); Guidelines on FBI Use of Informants and Confidential Sources, reprinted in SELECT CoMmITTEE REPORT, supra note 6, at 520 (listing factors to consider in determining suitability and reliability of informants).

${ }_{177} \mathrm{~A}$ bad track record would obviously weigh against a finding of credibility. Errichetti and Silvestri demonstrated on numerous occasions that they could not be relied on to refrain from involving innocent people in corrupt activities. Nevertheless, the FBI took action solely on these informants' naked assertions of a target's corruptibility. See Hearings, supra note 9, at 972-75 (testimony of Jerry J. Berman, Legislative Counsel, American Civil Liberties Union).

${ }^{178}$ See Weiner, 46 Charged After 'Sting' in S. Philadelphia, Philadelphia Inquirer, Nov. 2, 1984, at A1, col. 6 .

${ }^{170}$ See Dickerson, The FBI, in a 31/2-year-long Sting, Dropped Its Net Over Chicago Courts, Philadelphia Inquirer, Sept. 2, 1984, at F3, col. 3.

180 See, e.g., United States v. Mandel, 591 F.2d 1347 (4th Cir. 1979).

181 Although there had been criminal abuse of the private immigration bill pro- 
It is important that a magistrate not rely upon evidence uncovered in a wide-reaching, long-term operation like Abscam to establish reasonable suspicion of an individual subject's criminality unless the operation was itself justified. ${ }^{\mathbf{1 8 2}}$ Otherwise, even if the broad-based scam had no independent justification, it could provide the initial justification for the individual stings. This process would introduce evidentiary bootstrapping into the reasonable-suspicion inquiry: an unwary innocent could be enticed into criminal activity by the initial operation, and the agents could then use these government-induced crimes to show reasonable suspicion of ongoing criminal involvement.

Within the confines of the Abscam operation itself, the FBI developed reasonable suspicion as to the corruptibility of several of the individual politicians ${ }^{183}$ to whom they offered criminal inducements. However, the information indicating that the Abscam targets were corrupt was obtained in the course of a general operation designed to test the criminal propensities of politicians at large, for which there was no prior justification. ${ }^{184}$ Under the reasonable-suspicion requirement, a general scam like Abscam would be permissible only after the FBI had developed reasonable grounds for believing that political corruption was a problem in a particular geographical area or legislative body. ${ }^{185}$

\section{Reasonable Undercover Methods}

Standards of reasonableness will control the execution as well as the initiation of the undercover operation. ${ }^{188}$ The investigator's ability to alter the structure of the operation, and the particular tactics used to achieve the undercover goal, will be governed not by per se rules, but by their reasonableness given the facts of each individual case. Thus,

cess, see United States v. Helstoski, 442 U.S. 477 (1979), there was no recent evidence of even an unreliable nature that immigration bills were being sold by members of Congress when FBI operatives launched the so-called Asylum Scenario of Abscam, see Hearings, supra note 9, at 964 (testimony of Jerry J. Berman, Legislative Counsel, American Civil Liberties Union).

${ }^{182}$ Cf. $3 \mathrm{~W}$. LaFave, Search and Seizure: a Treatise on the Fourth AMENDMENT $\$ 11.4$, at 612 (1978). Frequently, "challenged evidence is 'secondary' or 'derivative' in character. . . . In these situations, it is necessary to determine whether the derivative evidence is 'tainted' by [prior government misconduct]. To use the phrase coined by Justice Frankfurter, it must be decided whether that evidence is the 'fruit of the poisonous tree." Id. (citing Nardone v. United States, 308 U.S. 338 (1939)).

188 See Hearings, supra note 9, at 969 (testimony of Jerry J. Berman, Legislative Counsel, American Civil Liberties Union).

184 See id. at 964.

185 See id. at 988-89.

${ }^{188}$ See Gershman, supra note 14, at 1588 ("The 'reasonableness' criterion will encourage courts to avoid the unsatisfactory 'end-justifies-the-means' analysis employed by the Abscam courts.") 
while any encouragement tactic will be narrowly tailored to achieve the legitimate purpose of testing the criminal propensities of one reasonably suspected of crime, ${ }^{187}$ the warrant authorizing the activity will be flexible enough to allow for reasonably necessary amendment as required by the fluid circumstances of the undercover operation. ${ }^{188}$ The appropriateness of the tactics relied upon to induce the commission of crime will be evaluated not according to categorical prohibitions, but according to what is necessary to ensure the commission of crime by those reasonably suspected of wrongdoing.

The warrant will include a description of the structure of the proposed inducement, but this structure must be amenable to sudden, unforeseen changes in the circumstances of the investigation. Thus, there should be an exception to the warrant requirement in the case of exigent circumstances comparable to that available in the search-andseizure area. ${ }^{189}$ Certainly, if an officer is suddenly apprised of an individual's dangerousness and is in a position discreetly to offer the individual an opportunity to commit an illegal act, the officer should not be required to secure a warrant beforehand. Similarly, if in the course of an investigation into the potential criminality of one suspect, a person not mentioned in the warrant expresses interest in participating in the criminal enterprise, the agent could make an offer to that individual under the exigent-circumstances exception. ${ }^{190}$ However, any major, deliberate shift in target or emphasis would require prior authorization. ${ }^{101}$ Furthermore, if an entrapment scheme turned sour as it became clear that the target was not interested in taking the bait, reasonable suspicion would disappear and the warrant would no longer be

${ }^{187}$ The requirement that the undercover methods be narrowly tailored to the situation can be compared to the particularity requirement for search warrants. See, e.g., U.S. CoNST. amend. IV (warrant must "particularly describ[e] the place to be searched, and the persons or things to be seized"); Coolidge v. New Hampshire, 403 U.S. 443, 467 (1971) (problem with general warrant "is not that of intrusion per se, but of a general, exploratory rummaging in a person's belongings); Stanford v. Texas, 379 U.S. 476, 485 (1965) (particularity requirement leaves nothing to discretion of officer).

${ }^{188}$ Cf. 18 U.S.C. $\S 2518(5)$ (1982) (allowing for extension of warrant); 50 U.S.C. $\S 1805(\mathrm{~d})(2)$ (1982) (same).

189 See Vale v. Louisiana, 399 U.S. 30 (1970) (establishing exigent-circumstances exception to the fourth amendment warrant requirement in search-and-seizure cases).

100 As in the cases upholding a warrantless seizure of suspicious items in plain view when the officer's access to the item has some prior justification, an undercover agent could make an offer when discovery of potential criminality is inadvertent. $C f$. Texas v. Brown, 460 U.S. 730 (1983) (upholding warrantless seizure of balloon after valid stop of defendant's car).

102 The unauthorized shift in targets and emphasis was the worst aspect of the Abscam operation. See supra notes 56-77 \& 159 and accompanying text. 
valid. ${ }^{192}$

The approach proposed here addresses many specific concerns expressed by commentators and courts about particular inducement techniques. Practices particularly deplored include the offering of excessive inducements, ${ }^{193}$ government provision of contraband, ${ }^{194}$ manipulation of a subject's sympathy, ${ }^{185}$ and repeated goading. ${ }^{186}$ Under the reasonableness standard advocated in this Comment, there would be no per se rule against the use of these techniques. However, because such undercover tactics would be unreasonable in almost all instances, a magistrate would very rarely be justified in approving them.

Generally, the agents' reliance on techniques such as excessive inducements and provision of contraband would indicate that the target is not predisposed in any meaningful sense and does not pose a real threat to society. Consequently, any law enforcement resources devoted to apprehending such a target would be squandered. In extreme cases, however, circumstances may justify the use of manipulative undercover methods. Magistrates should, therefore, have the leeway to permit otherwise excessive tactics when the exigencies of the situation render these ploys reasonable.

Some commentators have suggested a per se prohibitory rule against excessive inducements. ${ }^{197}$ According to this view,

If the inducement is unlikely to be replicated, then a defendant responding to it poses little danger, and the enforcement costs are largely wasted. If the inducement is unusually attractive, then the possibility of deterring those tempted to succumb is small, and the effort to deter them may again produce a less than optimal allocation of resources. ${ }^{108}$

A requirement that financial inducements mirror the opportunities available in the real world is a hallmark of proposals for entrapment

192 Fourth amendment search doctrine requires that a search cease when the items described in the warrant have been found and allows the search to be conducted only in places where those items might be concealed. See 2 W. LAFAvE, supra note 182, at $\S$ 4.10.

${ }^{193}$ See United States v. Jannotti, 501 F. Supp. 1182, 1200 (E.D. Pa. 1980), rev'd, 673 F.2d 578 (3d Cir.) (en banc), cert. denied, 457 U.S. 1106 (1982).

194 See, e.g., SELECT CoMmITTEe REPORT, supra note 6, at 362 (recommending a finding of entrapment per se where contraband could not have been obtained without government participation).

196 See, e.g., Dix, supra note 14, at 264-65.

108 See, e.g., id. at 260-61.

107 See, e.g., Gershman, supra note 14, at 1587-90; Select Committee REPORT, supra note 6 , at 362 .

198 Seidman, supra note 14, at 142-43; accord Dix, supra note 14 , at 267,270 71; EDWARDS COMMITTEE REPORT, supra note 6, at 37. 
reform. ${ }^{189}$ However, critics have pointed out that whether or not an inducement is outrageous will depend largely on the circumstances and situation of the individual target. ${ }^{200}$ The price paid to a wealthy member of the United States Congress to compromise his office may be extremely high, but nevertheless justified. ${ }^{201}$ This observation does not vitiate the argument that financial inducements must reflect the real world, but supports the position that limits on inducements must be determined by what is reasonable in each situation. The appropriate level of inducement should be decided by magistrates at warrant hearings on a case-by-case basis.

Another circumstance that some have urged should automatically trigger an acquittal on the ground of entrapment is the provision of contraband to the target by government agents. ${ }^{202}$ However, such a rule would be too strict, for it would eliminate some justified, well-run operations. When undercover investigators attempt to infiltrate an illegal business operation, such as a narcotics ring, it is not necessarily unreasonable for them to supply contraband to the suspects under investigation, especially if such action will gain the suspect's confidence. ${ }^{203}$ In fact, in some cases the only effective way for agents to apprehend a suspect may be by assuming the role of dealers or otherwise supplying

199 See, e.g., Dix, supra note 14, at 267, 270-71. But see SELECT COMMITTEE REPORT, supra note 6, at 370 (finding that federal law enforcement officials' use of unacceptable police tactics, such as threats, manipulation of the target's personal life, and provision of the sole source of illegal goods, is not of "sufficient frequency" to justify broad legislative reform).

200 See Select CommitTeE RePORT, supra note 6, at 370-71.

${ }^{201}$ See, e.g., United States v. Williams, 705 F.2d 603, 620 (2d Cir. 1983), cert. denied, 104 S. Ct. 524 (1984).

${ }^{202}$ See, e.g., United States v. Bueno, 447 F.2d 903 (5th Cir. 1971); United States v. Chisum, 312 F. Supp. 1307 (C.D. Cal. 1970). The Supreme Court has rejected this approach. See United States v. Russell, 411 U.S. 423 (1973). In Russell, the defendant had a "speed" shop in which he produced methamphetamine. The agent offered to supply him with phenyl-2-propanone, an essential ingredient for the production of the illegal drug, in return for one-half of the drug produced. The Supreme Court, in an opinion by Justice Rehnquist, overturned the appellate court's determination that, notwithstanding the defendant's admitted predisposition, he should be acquitted because of the " intolerable degree of governmental participation in the criminal enterprise." Russell, 411 U.S. at 427 (quoting United States v. Russell, 459 F.2d 671, 673 (9th Cir. 1972)). In Hampton v. United States, 425 U.S. 484 (1976), the Court went further by holding not only that the defense of entrapment was unavailable because of the defendant's predisposition, but also that the defendant had no valid due process claim, despite the fact that the government had both supplied the drug to him and purchased it from him. Justice Brennan protested that "[t]he Government is doing nothing less than buying contraband from itself through an intermediary and jailing the intermediary." Id. at 498 (Brennan, J., dissenting) (citing Bueno, 447 F.2d at 905).

${ }^{203}$ The dissenters in United States v. Russell, 411 U.S. 423 (1973), took a different view, considering such involvement in the commission of the crime to be "precisely the type of governmental conduct that the entrapment defense is meant to prevent." Id. at 447 (Stewart, J., dissenting). 
contraband.

Rather than adopting a per se rule, a magistrate should ascertain the availability of the disputed ingredient. ${ }^{204}$ This inquiry would help determine whether the government's supplying of contraband was reasonable. If the contraband is impossible or nearly impossible to obtain because of either its scarcity or the subject's limited resources, the government's supply of it would render "the offered opportunity an unreliable indicator of the subject's general dangerousness."205 In other words, if the contraband in question is generally unavailable, it would be impossible to develop the required level of reasonable suspicion before the fact. If, however, the contraband is generally available to the target from sources other than the government, it may be reasonable to allow the agents to provide it.

The manipulation of a subject's emotions, whether it be through sympathy, personal loyalty, or sexual favors, ${ }^{206}$ is another tactic that would lead some observers to find entrapment per se. The exploitation of Sorrells' sentimentality ${ }^{207}$ and Sherman's pity ${ }^{208}$ arguably explains their acquittals, regardless of the doctrinal approach followed. In narcotics cases, such appeals to sympathy are apparently not uncommon. In one case, the officer pretended to have a withdrawal seizure on the sidewalk, and importuned a passerby to procure heroin for him to relieve his misery. ${ }^{209}$ In another, an informant friendly with the defendant begged the defendant to secure heroin for him because "he was sick and needed something."'210

Emotional manipulation would never meet the standard of reasonableness. Such practices offend not only because they play unfairly upon generous human impulses, but also because their use suggests that there was a lack of real justification for testing the virtue of these individuals. If any identifiable grounds of suspicion existed in these cases,

204 Cf. The Attorney General's Guidelines on FBI Undercover Operations, reprinted in SELECT COMMITTEE REPORT, supra note 6, at 539-41 (operation may not be initiated without express authorization by the Undercover Operations Review Committee and the Director of the FBI if an individual working through the FBI "will seek to supply an item or service that would reasonably be unavailable to criminal actors but for the participation of the government").

205 Dix, supra note 14, at 277.

206 See id. at 261-63.

207 See Sorrells v. United States, 287 U.S. 435 (1932).

208 See Sherman v. United States, 356 U.S. 369 (1958).

209 See United States v. Sawyer, 210 F.2d 169, 170 (3d Cir. 1954). In Sawyer, the defendant's conviction by the district court was overturned in part because the judge did not properly instruct the jury on the entrapment defense. See id. at 170.

${ }_{210}$ See State v. Randolph, 290 A.2d 919, 919 (Del. Super. Ct. 1972). In Randolph, the court rejected the entrapment defense on the ground that the defendant showed no reluctance to buy the contraband. See $i d$. at 920 . 
there would be no reason to resort to such tactics. Therefore, under the reasonable-suspicion approach, such activities would always be unwarranted. ${ }^{211}$

Another element that may have tipped the balance in favor of defendants Sherman and Sorrells was the persistence with which their seducers goaded them. ${ }^{\mathbf{2 1 2}}$ However, at least one commentator opposes a per se rule against repeated urgings. ${ }^{213}$ It may well be that the wary criminal needs to be importuned several times before agreeing to the proposed transaction. If a specific number of offers is established as an upper limit, underworld figures will quickly learn how many times they have to say "NO!" to ensure a strong case for a dismissal of the prosecution on entrapment grounds. Thus, a flexible rule of reasonableness should govern the persistence with which officials may urge the target to break the law.

Agents must bear in mind, however, that there will be times, as the case of the unfortunate Mr. Sherman poignantly demonstrated, when several refusals will indicate that whatever suspicion the detective had of the subject's criminal intent was mistaken. In such a case, further importunings will be beyond the scope of the warrant, because any reasonable suspicion of the subject's criminality will have disappeared. This particular aspect of reasonableness will be more difficult to insure than the others, because the decision is more subjective and must be made by agents in the course of the operation. However, officials may be deterred from improper encouragement tactics by the knowledge that if they exceed the authority granted to them in the warrant, the eventual prosecution of the target will be barred at a pretrial hearing.

Under the standard of reasonableness advocated in this Comment, police encouragement tactics must be narrowly tailored to the circumstances of each case. If the circumstances change during the course of the operation, and reasonable suspicion remains, the magistrate may give government officials greater leeway to devise means of luring suspects into their hands. The exact methods employed will vary, so that techniques that would be unreasonable when directed at some targets will be acceptable means of apprehending others. Exploitation of sympathy will never be a reasonable undercover tactic. Excessive inducements and supplying contraband will almost never be reasonable, al-

211 While playing on a target's sympathy or loyalty would be unwarranted, an agent would still be allowed to "make friends" with the target. Indeed, this course of -action may be the only way that agents can penetrate an illegal operation.

212 Sorrells was asked for whiskey three times, see Sorrells v. United States, 287 U.S. 435, 439 (1932); Sherman acceded to Kalchinian's demands only after "a number of repetitions," Sherman v. United States, 356 U.S. 369, 371 (1958).

${ }^{213}$ See Park, supra note 13, at 228. 
though some circumstances may call for such techniques. Finally, the validity of repeated urgings will vary from situation to situation and will require greater reliance on the independent judgment of the officer on the scene.

\section{CoNCLUSION}

The high stakes and drama that characterized the Abscam and DeLorean operations illustrate vividly both the appeal and the danger of elaborate, high-visibility undercover scams. The targets in these operations were not of the highest moral caliber, as they demonstrated by yielding to the temptations offered, but that does not necessarily mean that they would have committed like crimes in the absence of FBI encouragement.

There is something very frightening about the notion that the police are free to test the morality of individual citizens without restraint. To address this fear, this Comment has argued that law enforcement officials should be required to demonstrate reasonable suspicion that an individual is engaging in criminal conduct before they will be authorized to test that individual's penchant for illegal transactions. Furthermore, reasonableness should govern every stage of the operation, so that investigations validly initiated remain justified.

The Burger Court is cutting away at the body of law developed by the Warren Court to protect individuals from overreaching by law enforcement bodies. Large-scale undercover operations like Abscam provide these institutions with unprecedented power to interfere with our lives. It is up to Congress to restrain this power by enacting certain and enforceable limits on the ability of the executive branch to lead citizens into temptation. 